
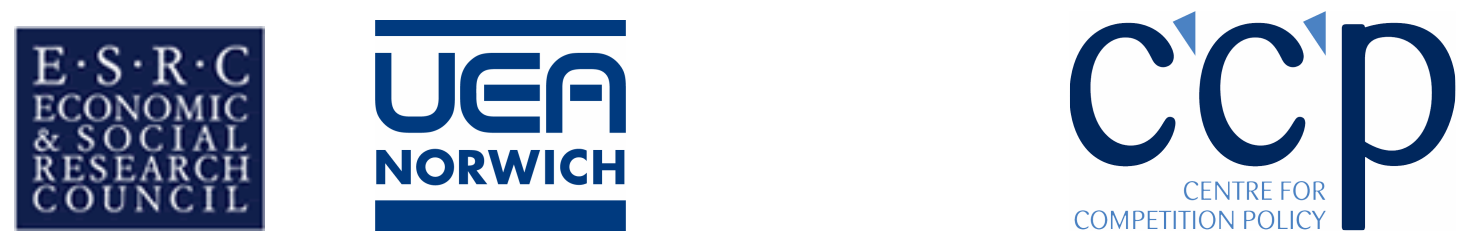

\title{
Dynamics of Internet Banking Adoption
}

\author{
by \\ Yoonhee Tina Chang \\ ESRC Centre for Competition Policy, University of East Anglia
}

\section{CCP Working Paper 06-3}

\begin{abstract}
This paper analyses the behaviour of banks' customers when a new technology (internet banking) is introduced. The determinants of consumer adoption of internet banking are characterised using survey data from Korea in both static and dynamic framework. There is evidence that adoption of internet banking is influenced by sex, age, marital status, degree of exposure to internet banking, and the characteristics of the banks. A duration analysis shows no evidence of first mover advantage (order effects) in internet banking whilst the largest bank (rank effects) in commercial banking remains dominant in internet banking. The results imply that the internet banking adoption is dominated by social norm effects.
\end{abstract}

October 2005

JEL Classification: D80; G21; G28; L00; L89; O33

Keywords: Internet Banking, Technology Adoption, First-Mover Advantage, PreEmption, Social Norm

Acknowledgements:

I am grateful for encouragement and many helpful comments from Keith cowling and Jeremy smith. I also thank, Wiji Arulampalam, Massimiliano Bratti, Jonathan Cave, Matthew Haag, Margaret Slade, Mark Stewart, Mike Waterson and participants at the University of Warwick workshops, the EARIE 2002, EUNIP 2002, RES 2003, and IIOC 2004 for comments and discussions. The support of the Economic and Social Research Council is gratefully acknowledged. All errors are mine.

Contact details:

y.chang@uea.ac.uk, ESRC Centre for Competition Policy, University of East Anglia, Norwich, NR4 7TJ, UK. www.ccp.uea.ac.uk t: +44 (0) 1603593715 f: + 44(0) 1603 591622

ISSN 1745-9648 


\section{Introduction}

This paper is concerned with examining the behaviour of firms (banks) and consumers (banks' customers) in the event of a new technology (internet banking) introduction. The banking industry has been significantly influenced by evolution of technology. ${ }^{1}$ The growing applications of computerised networks to banking reduced the cost of transaction and increased the speed of service substantially. For instance, Table 2 shows that a banking transaction using a branch teller costs 100 times more than that via internet. In addition, the speed of service is improved as customers do not have to physically travel to a branch. The nature of financial intermediaries made banks improve their production technology by focusing on distribution of products. In other words, the evolution of banking technology has been mainly driven by changes in distribution channels as I see evidence from over-the-counter (OTC), automatedteller-machine (ATM), phone-banking, tele-banking, pc-banking and most recently internet banking (IB). ${ }^{2}$

Network effects and standardisation have become topical research subjects with the growing number of networked industries. The application of new technologies, including the internet, has created new ways of doing business. For instance, internet application to e-commerce and finance has certainly changed the business environment. In the presence of network effects and standardisation, technology intensive industries seem to establish concentrated market structure. ${ }^{3}$ Hence, it seems natural to consider progress in banking technology as a reason for market consolidation, given the nature of the network in banking. However, there are only a few studies on consumer behaviour relative to the vast amount of literature on firms' behaviour regarding technology adoption and market structure. I argue that customer inertia and risk aversion in characterising internet banking users (IBU)

\footnotetext{
${ }^{1}$ See Hannan and McDowell (1984), Haynes and Thompson (2000), Gourlay and Pentecost (2002)

${ }^{2}$ The FSS in Korea defines the internet banking as computer network based banking, which includes automated transfer of money, settlement of bills, and realisation of general financial service network. On the other hand, Cave and Mason (2001) define internet as a global network of networks. Their paper elaborates the mechanism of internet

${ }^{3}$ For example, the internet browser industry has two leading technologies Netscape and Microsoft Internet Explorer. VHS vs. Beta Max in the 70s can also be a good example. On the other hand, Hannan and McDowell (1984) investigate a concentrated market structure in banking with respect to
} 
suggest that aggressive expansion in internet banking is simply a pre-emptive action by banks with little impact on the market structure.

This paper uses online survey data from Korea on internet banking to analyse the adoption pattern of banking technology diffusion across customers. ${ }^{4}$ Firstly, I characterise the determinants for consumer adoption of a new banking technology (internet banking). I examine the internet banking adoption process in both a static and dynamic framework to explain why new banking technologies are not always taken up by the mass-market. Subsequently I identify different characteristics between early adopters and late (i.e. delayed) adopters using parametric and semi-parametric duration models and show how the results differ between different model specifications.

I investigate empirical issues of banking technology concerning customer inertia, risk aversion and pre-emption. I find evidence that given the possibility of multiple equilibria when the bank products are incompatible, the reputation of the bank becomes important. The new banking technology can also face excess inertia as bank customers are somewhat tied to old technologies. More importantly, risk aversion plays an important role in determining the probability of adoption. Furthermore, I show these empirical issues related to internet banking provide grounds for incumbent banks to take pre-emptive actions.

On the other hand, with continuous introduction of new technologies in banking, additional concerns were raised regarding new ways of banking. As the survey by the Bank of International Settlements (BIS, 2000) pointed out, most Governments believe that new supervisory or regulatory measures are necessary for internet banking although it will take time for them to prepare prudential regulatory guidelines. On the basis of my results, I show the relevant banking regulation has an important implication for adoption of a new banking technology.

I find evidence that adoption of internet banking is influenced by sex, age, marital status, and degree of exposure to internet banking as well as the characteristics of the banks. I also find the adoption is dominated by social norm effects. Using a duration analysis, I find no evidence of first mover advantage (order effects) in

the diffusion of ATM machines. Sutton (1999) also illustrates network effects and standardisation in detail with respect to market structure.

${ }^{4}$ Korea refers to South Korea throughout this paper. 
internet banking whilst the largest bank (rank effects) in commercial banking remains dominant in internet banking.

In section 2, I describe the new banking technology (internet banking) and factors likely to affect its diffusion. Section 3 investigates theoretical and empirical literature related to technology diffusion. I develop and compare econometric models of adoption in Section 4 and report a descriptive summary and the results from the static models in Section 5, the results from the duration models in Section 6, and the results for non-internet banking users in Section 7. Finally, Section 8 concludes with some policy discussions.

\section{Overview of Internet Banking}

One might remember the days when a person had to go to a bank branch to deposit or withdraw money and get a bank statement book manually updated by a teller over the counter (OTC). With the introduction of computer networks, a networked printing machine started replacing the manual update of statements. Then, cash dispensers (CDs) and automated teller machines (ATMs) were introduced to facilitate withdrawals, deposits and even transfers accommodating mobility in much wider geographical areas. Phone banking was a revolutionary concept in banking since it made banking accessible from anywhere as long as phones were available. With the successful diffusion of mobile phones, phone banking is moving into a next phase of development. However, one of the most substantial changes in banking technology is the recent introduction of internet banking. 
Table 1 Comparison of Banking Delivery Channels in Korea

\begin{tabular}{|c|c|c|c|c|}
\hline & Internet Banking & Mobile Banking & Phone Banking & $C D / A T M$ \\
\hline Delivery Channel & PC, Internet & Mobile Phone & Phone & $\begin{array}{l}\text { CD/ATM } \\
\text { terminal }\end{array}$ \\
\hline \multirow{4}{*}{$\begin{array}{l}\text { Diffusion of } \\
\text { technology }\end{array}$} & PC: & \multirow[t]{4}{*}{$23.4 \mathrm{~m}(54 \%)$} & \multirow[t]{4}{*}{$20.8 \mathrm{~m}(48 \%)$} & \multirow{4}{*}{$\begin{array}{l}0.04 \mathrm{~m} \\
(0.9 / 1000 \text { pers })\end{array}$} \\
\hline & $10 \mathrm{~m}(0.23 /$ pers $)$ & & & \\
\hline & Internet: & & & \\
\hline & $16 \mathrm{~m}(37 \%)$ & & & \\
\hline Information type & $\begin{array}{l}\text { Text, Audio- } \\
\text { visual }\end{array}$ & Text & Audio & $\begin{array}{l}\text { Text, Audio- } \\
\text { visual }\end{array}$ \\
\hline Cash transaction & N/A & N/A & N/A & Available \\
\hline Location & Home, work & No restriction & No restriction & Main streets \\
\hline \multirow[t]{2}{*}{ Visual } & Good & Limited & None & Good \\
\hline & Wide-screen & Small-screen & & Wide-screen \\
\hline Manual & $\begin{array}{l}\text { Need to use } \\
\text { keyboard }\end{array}$ & $\begin{array}{l}\text { Uneasy with small } \\
\text { button }\end{array}$ & Push button & Touch panel \\
\hline Mobility & low & high & low & N/A \\
\hline $\begin{array}{l}\text { Information } \\
\text { search/memory }\end{array}$ & Available & N/A & N/A & N/A \\
\hline Terminal fee & High on customer & Low on customer & Low on customer & High on banks \\
\hline Networkfee & On customer & On customer & On banks & On banks \\
\hline
\end{tabular}

From the comparison of banking delivery channels presented in Table 1, I first notice that the evolution of banking technology from CD and ATM to internet makes banking transaction more mobile (or less locational restriction) at a lower fee at the terminal. In addition, internet added a new feature of information search in banking when it retains the advantage of various information types, e.g. in text and audiovisual, which are provided by CD and ATM. However, despite the benefits of internet banking, this medium has not yet replaced traditional banking channels and the banking industry seems to maintain the multi-channel distribution approach.

\section{Innovation:}

As illustrated above, banking technology has focused on reducing cost of distribution. In Table 2 I notice a transaction via phone banking costs less than a half of the cost via branch banking. This cost per transaction halves for banks when the customer 
switches from phone banking to using ATMs. However, the reduction in cost of distribution is much more significant when the customer switches to PC or internet banking, which is nearly hundred times less costly.

Table 2 Cost per Transaction in the US: Money Transfer

Unit: US dollars

\begin{tabular}{lcccccc}
\hline Type & Branch & Cheque & Phone & ATM & PC & Internet \\
\hline $\begin{array}{l}\text { Cost per } \\
\text { transaction }\end{array}$ & 1.07 & 0.95 & 0.45 & 0.27 & 0.015 & 0.01
\end{tabular}

Source: Furst, Lang \& Nolle (1998), Booz- Allen \& Hamilton (Apr.1997)

In this context, I consider internet banking as a process innovation that makes customers handle their banking without going to bank tellers at a lower price given the lower cost to the bank. In addition, it allows new customers to visit virtual banks via public web-network whilst phone-banking and PC-banking provide only closed network limited to the existing clients. Considering new products and services specifically designed and offered on the internet given the new technology feature, one might also argue that internet banking has an aspect of product innovation as well. ${ }^{5}$

\footnotetext{
${ }^{5}$ Most banks offer comprehensive personal financial management packages on the internet. For example, the package is tailor made for each client combining commercial banking, investment in stockmarket, bondmarket, and mutual funds and sales of insurance products and pension schemes.
} 


\section{Products and Services:}

Regarding product innovation tied to internet banking, increasing competition amongst the leading banks also promotes product and service differentiation. For example, despite the Internet Banking System (www.banktown.com) developed in 1999 by the consortium led by Korea Telecom and several banks, most leading internet banking providers are now using their own system to differentiate their service products rather than using Banktown. Moreover, banks offer comprehensive asset management packages on the internet putting together non-traditional banking products (bundling).

Table 3 Services Available on Internet Banking in Korea

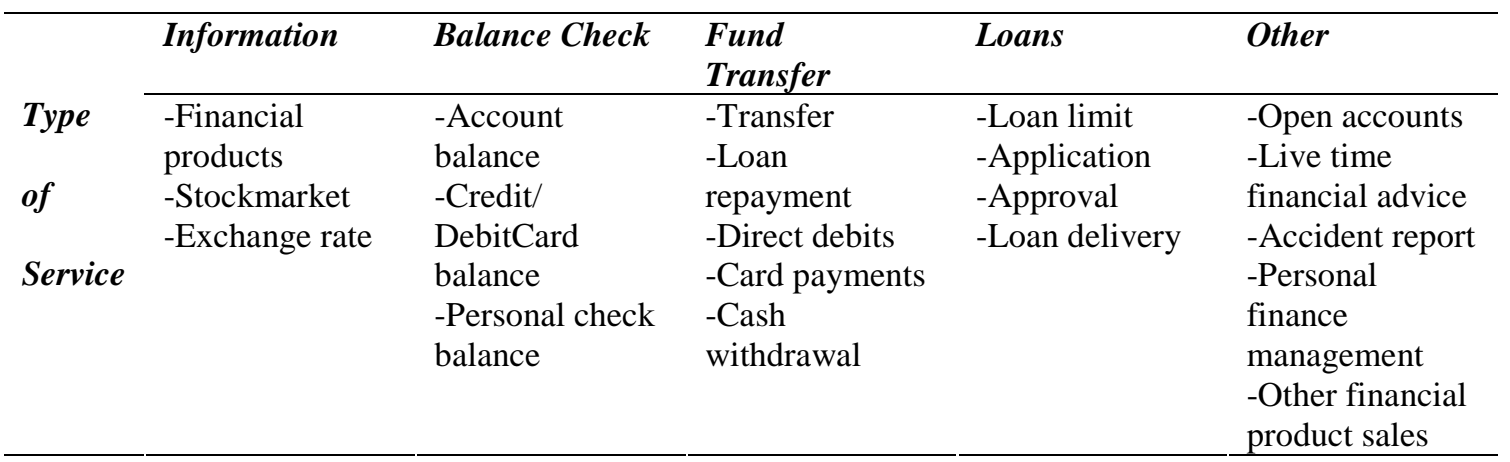

Source: Bank of Korea 2002

Currently all 17 commercial banks in Korea are providing internet banking although their range of services may vary. Table 3 summarises the services available on internet banking into 4 main areas: 1/ information search engine; 2/ balance check; 3 / fund transfer, and 4/ activities related to loans, in addition to the basic services such as opening an account, financial product sales and etc. Although internet banking does not have the same capacity as CDs and ATMs in delivering cash, there are many more informational features which enable customers to search for appropriate products and services; make a decision, and act on it over the internet. One important observation to make is that customers need to become more proactive in their information search in the absence of bank tellers or financial advisors on the phone. 


\section{Competition:}

Banking competition is assessed in three different ways, price (interest rate), quantity (deposit and loan size) and quality (reputation-relationship). Traditionally banks have competed in branch network (quantity) to increase the number of clients, i.e. the deposit and loan size. However, with the benefit of new technologies, the quantity competition seems to be replaced by the network competition in ATM or internet banking. Internet creates a potentially competitive market outcome in the presence of both internal and external threats. Threats within the industry increase as product and service information becomes more transparent on the internet. On the other hand, there are external threats with lower entry barriers for those with advanced technology in internet. It would be interesting to see if changing competition environment would have an impact on market structure.

\section{Diffusion:}

"While the dot-com party may be over, U.S. retail bankers are just beginning to celebrate their online banking accomplishments. With national adoption rates reaching $20 \%$ in North America, online banking is becoming a mainstream phenomenon. Twenty percent, however, is just the tip of the iceberg. Banks in Nordic countries and South Korea have pushed adoption beyond 35\%," (Alenka Grealish from Celent Report 14 Nov. 2002)

Korea has been quoted as a country with one of the highest internet banking penetration ratios per head alongside Scandi-Nordic countries and Canada. The internet banking user map (Figure 11) produced by BOK in 2002 illustrates that $60 \%$ of the population use internet and 35\% internet banking users. This high penetration ratio is realised as a result of the infrastructure of the internet network in Korea, the high-speed network in particular. According to Ofcom's (2004) Strategic Review of Telecommunications Phase I Consultation, Annex H23, the broadband take-up in Korea is increasing significantly faster than in other countries. This consultation report also points out the public financing in the network infrastructure as one of the 
reasons for the high rate of broadband take-up. Given the network infrastructure, currently almost a half of the population is using the internet banking, e.g. 24.3 million out of 47.9 million (BOK, 2004).

"As of December, 2004, the number of users of internet banking services in twenty domestic banks (excluding the Korea Development Bank $(K D B)$ and the Export-Import Bank of Korea), Citibank and post offices amounted to 24.3million. This represented a 6.7 percent increase from 22.8 million at the end of December 2003." (Bank of Korea 2005, Press Release 2005-1-38, p.1)

Internet banking was first introduced by Chohung Bank in Korea at the beginning of 1998, which was followed by rival banks throughout 1998. The number of banks which offer internet banking reached 13 by the end of 1999 and continuously increased to 20 by the end of 2000 and currently all 14 commercial banks offer internet banking alongside four specialty banks (cooperatives), two foreign banks, postal savings, and district banking corporation (Saemaul Geum-ko). ${ }^{6}$ Not only the speed of internet banking adoption by banks has been extraordinary but also the adoption by customers has been extremely fast. The number of registered internet banking users has nearly doubled every quarter until the end of 2000, since when the speed of adoption has slowed down. It is worth identifying why so many people adopted internet banking at such an extraordinary speed.

\section{Background Literature and Facts}

The importance of technological progress in economic growth and social welfare has long been recognised by many economists. Schumpeter (1934, 1943) pioneered studies on technology, which was subsequently emphasised by Solow (1957) in his economic growth literature. Schumpeter's view on technology rejected the anti-trust orthodox and argued large firms operating in a concentrated market structure would

\footnotetext{
${ }^{6}$ The information is as of Dec. 2004.
} 
encourage technological progress, whilst Solow claimed that a good proportion of growth residual might be explained by changes in technology. On the other hand Davies (1979) argued that society fully benefits from a process or product innovation only when the innovation is diffused enough to enhance the firm's productivity or the consumer's utility. However, most of the earlier literature on technological progress focused on the firm's behaviour analysing how process innovation would influence its productivity. On the other hand, the consumer behaviour in relation to product innovation has been less frequently discussed. ${ }^{7}$

Gourlay and Pentecost (2002) points out that research into the inter-firm diffusion of new technology has paid relatively little attention to the determinants of innovation diffusion in the financial sector compared to other industries. In addition, study on consumer behaviour of financial technology adoption is almost next to none.

Amongst various approaches in analysing technology-intensive industries, network effects have recently become important topics with the growing applications of internet network. ${ }^{8}$ Katz and Shapiro (1985) examines network compatibility as an element of competition and shows consumers' expectations on externalities play an important role in determining an equilibrium, in other words, firms' reputations are important. They also claim that consumers' benefit from the use of a product increases when there is a large number of other consumers purchasing compatible items (Katz and Shapiro, 1986). In internet banking, the installed base should also increase customer utilities via physical network. Another important contribution of their work is intertemporal substitution in technology adoption. Some consumers may choose to wait for cost and demand uncertainty to be resolved before they commit themselves to a specific technology. This aspect is yet to be proved empirically in banking technology.

Farrell and Saloner (1986) also investigate installed base and compatibility. ${ }^{9}$ They claim a new standard can face excess inertia as installed-base users are somewhat tied to the old technology, which explains why new technologies are not always taken up by the mass-market. More recently, Mason and Weeds (2001)

\footnotetext{
${ }^{7}$ In the same context, Waterson (2003) draws attention to consumers' reluctance to search and switch suppliers in relation to competition and competition policy analysis.

${ }^{8}$ Saloner and Shepard (1995) acknowledge the importance of networks with the recent proliferation of information technology.

${ }^{9}$ Installed base represents the number of users who are networked via a technology.
} 
identify three different inefficiencies of premature adoption in the presence of network externalities and examine the effects of uncertainty, network effects and preemption on inefficiencies.

Early epidemic models of diffusion use an analogy between the contact among firms or consumers and the spread of disease (Mansfield, 1968). For example, some consumers adopt a new technology before others because they happen to become infected first. Similarly, some technologies diffuse faster than others, as they are more contagious due to its profitability and risk factors. In contrast, Karshenas and Stoneman (1993) point out that contemporary approaches have put less emphasis on information spreading as the key explanatory variable of innovation diffusion. Then, they summarise the recent approach into three different mechanisms:

1/Rank effects, suggest that only firms with sufficiently high ranking will adopt when an innovation first becomes available. However, as the cost of adoption falls over time, lower ranked firms will adopt as well. ${ }^{10}$

2/Stock effects, result from the assumption that are early movers obtain higher returns on the new technology and the marginal return of adoption decreases with an increase in the number of adopters. ${ }^{11}$

3/Order effects, are applicable when there is a fixed amount of critical input into production. In such situations, only early movers who secure access to the critical input will find it profitable to adopt. The order of adoption clearly matters.

Hannan and McDowell (1990) examine the impact of bank adoptions of automated teller machines (ATMs) on subsequent levels of concentration in local banking markets. They find strong support for the existence of rank effects in the diffusion of ATMs, while rejecting the existence of epidemic effects. However, their approach has to be further tested as they left out the aspects of consumer adoption, which I believe plays an important role in banking industry structure. They propose if larger banks adopt ATMs, markets tend to be more concentrated and vice versa.

\footnotetext{
${ }^{10}$ See Davies (1979) and Ireland and Stoneman (1986) for further examples of rank effects.
} 
However, the diffusion of a new banking technology is relatively fast across large and small banks nowadays and sometimes a government consortium leads the market toward a new technology simultaneously. ${ }^{12}$ Therefore, it is difficult to justify that market concentration is due to early adoption by larger banks.

Waterson (2003) suggests consumer search behaviour is sub-competitive in current account banking compared to motor car insurance and therefore the market structure tends to be more concentrated in banking than in motor car insurance. One of the main differences between the two industries lies in credit rating system. Bankspecific credit rating builds up over time whereas credit rating for motor insurance is transferable between insurance companies. Thus, long-term aspects of credit rating in banking may explain why consumers are reluctant to switch their banks. This coincides with my pilot test results where the majority did not switch their banks despite more favourable internet banking offers from rival banks.

Following Gilbert and Newbery's (1982) approach, I consider product differentiation on internet banking as a preemptive invention. I argue internet banking creates a new dimension of banking competition where banks compete in different networks via product diversification and differentiation. Fudenberg and Tirole (1985) also use a similar approach using the adoption of a new technology to illustrate the effects of pre-emption in games. However, they argue that threat of pre-emption equalises rents in a duopoly but does not extend to the general oligopoly. If the gain to pre-emption is sufficiently small, the optimal symmetric outcome (late adoption) is an equilibrium. This contrasts with Reinganum's (1981b) result in pre-commitment equilibria, which leads to diffusion. In other words, despite the small gain, the adoption of new technology prevails in oligopoly, especially when the information lags are short and firms can observe and respond to their rivals' actions. Reinganum (1981b) applies game theoretic approach to market structure to investigate firms' strategic behaviour in adoption of new technologies.

More recently, Akhavein et al. (2001) point out few quantitative studies on the diffusion of new financial technologies and the weakness where the technology is limited to ATMs. In the hazard model analysis, they suggest large banks innovate

\footnotetext{
${ }^{11}$ Reinganum (1981b) discusses the strategic behaviour of firms in this context.

${ }^{12}$ In Korea, the Korea Telecom consortium introduced the Internet Banking technology to most banks (www.banktown.com).
} 
earlier (pre-emption) and the tobit model also suggests banks with fewer separately chartered, but with more branches, innovate earlier.

Probably, it is most common to use duration model for analysis of technology diffusion whilst a game theoretic approach forms another group investigating diffusion of technology as a strategic reaction in games (Rose and Joskow, 1990; Karshenas and Stoneman, 1993; Saloner and Shepard, 1995; Gourlay and Pentecost, 2002). On the other hand, Stoneman and Battisti (2000) use Deaton and Muellbauer's (1980) model, which reflects the diversity of factors that impact the diffusion process. They assume a Weibull underlying distribution of diffusion, ${ }^{13}$ while drawing attention to the weakness of the epidemic model, which assumes underlying hazard rate is constant over time and all individuals have equal chance of getting the disease.

With internet banking, innovation certainly improves productivity via cost cutting in distribution but diffusion pattern amongst consumers is equally important. In order to link the firm behaviour and the consumer behaviour, I take some insight from behavioural studies on adoption.

Diffusion research did not develop from a single discipline. Different disciplines led to the development of this theory and the history goes back to Tarde's Laws of Imitation (1890, 1903), which conceptualised imitating behaviour using a selectionist rationale. Throughout the last century, his laws of imitation have influenced a substantial amount of diffusion studies across many disciplines, including sociology, anthropology, general economics and many others. Since Tarde, there have been a plethora of studies that have tried to link imitation within a social structure, consumer behaviour, industrial structure and welfare economics. However, the effort to link the above sociological aspects of economics were somewhat neglected recently with an increasing focus on technological development. Technological development could be one of the main factors for economic growth since the $20^{\text {th }}$ century. However, without identifying why and how consumers adopt new technologies in the social context, the research on technology is incomplete.

A similar example can be found as the Asian crisis has added new impetus to the quest for comprehending relationships between economy and culture whilst most research on Asia prior to the crisis focused on conventional macroeconomic variables, 
such as human capital and investment. Janelli and Yim (1997) criticise that a Western intellectual tradition has sought to dichotomise explanation of human actions into the ideal and the material and suggested the rational choice theory must be considered in the social context. It is important to recognise the existence of mutually supportive relationships between cultural understandings and the pursuit of development goal (material) in Korea. Greif (1994) uses a similar approach and argues that a path of economic growth is not a mere function of endowment, technology, and preferences but a complex process in which the organisation of society plays a significant role. The organisation of society reflects historical, cultural, social, political and economic processes.

According to Tarde (1903), consumers imitate from their immediate social contacts or networks. In this context, it is necessary to look at idiosyncratic Korean society and culture. Macdonald (1990) points out strong family ties and importance of community life in Korea. For example, Koreans tend to place the concept of "We" ahead of "I" and this leads the society to conformity and collectivity rather than individualism. Hence, it looks natural to see such a fast diffusion of internet banking in Korea whilst most developed countries are not yet ready to adopt internet banking as their main channels for banking. Koreans are known to conform to their social norm and the adoption of internet banking in this case is certainly perceived as their social norm which narrowed the socio-economic gaps by the conformity.

For diffusion, one of the most common approaches is applying social leader concept. Becker (1970) finds substantial correlation between an individual's adoption timing of an innovation and both his/her relative position in sociometric network and his/her most valued source of information and suggests that early adopters are opinion leaders. Rogers (1995) overviewed a vast amount of publications related to innovation diffusion and summarises socio-economic characteristics of adopter categories: early adopters to laggards. He also claims that opinion leaders are at the core of respective networks.

Another approach adopts rational decision process. Rosenberg (1976) argues that in many markets prospective buyers for an innovation are strongly influenced by expectations concerning the timing and significance of future improvements. In other

\footnotetext{
${ }^{13}$ Discussion on Weibull distribution will be later in section 3.4.
} 
words, the optimal decision process of innovation adoption depends on technological expectations and learning. As a similar approach of rational decision process, McFadden and Train (1996) explain when a new product with unknown attributes are offered, customers determine whether they like the product by trying it themselves or wait to observe the experience of other customers who try the product. They investigate the implications of learning from others on the sales of new products and the impact of advertising.

Rational decision approach can be useful for analysing early adopters of new technology as they are usually tech-savvy users. According to International Data Corporation report (IDC, 2002), early adopters of wireless internet are usually young (28 years old on average) and male (64\%) tech-savvy users. This report categorises consumers into 4 adoption stages along the S-shaped diffusion curve: 1/early adopters are dominated by male tech-savvy group, 2/early majority are young working group, 3/ late majority are young working group with larger female group, and 4/laggards are predominantly older group.

On the other hand, Stoneman and Diederen (1994) raise another important issue of public policy for technology diffusion. They explain diffusion may be too fast if firms adopt a technology before it is profitable to do so, or if firms adopt a new technology today that effectively preempts the adoption of a superior technology in the future. For instance, when customers are exposed to unidentifiable amount of risks via internet banking, the important role of public policy is to mitigate the risks in early adoption.

Rogers (1995) points out that a common problem in diffusion research is the individual-blame bias, i.e. the tendency to hold an individual responsible for his or her problems, rather than the system of which the individual is a part. Following the criticism, he suggested five main variables determining the rate of adoption. Table 4 presents his five variables, to which I link the potential attributes associated with internet banking, and which are: 1/ perceived attributes of innovations; 2/ type of innovation decision; 3/ communication channels; 4/ nature of the social system, and 5/extent of change by agents' promotion efforts. 
Furthermore, it is worth sketching out some cultural aspects of Korean society as diffusion is considered to be a social phenomenon and in doing so, the Confucian tradition and its impact on education would be the key elements.

Table 4 Adoption Variables and Attributes in Internet Banking

\begin{tabular}{|c|c|}
\hline Variables (Rogers, 1995) & Attributes in Internet Banking \\
\hline 1. Perceived Attributes of Innovations & $\begin{array}{l}\text { - Internet communication as a channel of } \\
\text { banking } \\
\text { - Flexible services in terms of time and } \\
\text { location }\end{array}$ \\
\hline $\begin{array}{l}\text { 2. Type of innovation-decision } \\
\text { (optional, collective, authority) }\end{array}$ & $\begin{array}{ll}\text { - } & \text { Optional } \\
\text { - } & \text { Collective considering Korean culture }\end{array}$ \\
\hline $\begin{array}{l}\text { 3. Communication channels } \\
\text { (mass media, interpersonal, etc.) }\end{array}$ & $\begin{array}{l}\text { Multi-channels: the survey suggests } \\
\text { interpersonal, mass-media, internet and } \\
\text { many others }\end{array}$ \\
\hline 4. Nature of the social system & $\begin{array}{l}\text { - Internet adoption as a social norm } \\
\text { - High degree of technological network } \\
\text { interconnection } \\
\text { - High degree of social network: strong } \\
\text { family tie, peer group and social clubs in } \\
\text { a broader sense }\end{array}$ \\
\hline $\begin{array}{l}\text { 5. Extent of change by agents' promotion } \\
\text { efforts }\end{array}$ & $\begin{array}{l}\text { - High effort level of promotion with } \\
\text { special offers on interest rates, fees, etc. } \\
\text { - Supported by Government institutions }\end{array}$ \\
\hline
\end{tabular}

Macdonald (1990) claims that the enormous importance attached to education in Korea is a principal reason for the nation's rapid development. This general attitude towards education is rooted in the Confucian tradition, where entry into government service was obtained through years of study of the Confucian classics, ${ }^{14}$ proven by examination. Among the traditional 4 classes of Caste; Sa (Scholar-official), Nong (farmers), Gong (Artisans, Engineers), Sang (Businessmen), the social ideal was the Sa (scholar-official) group. Back then, government positions were the only way to rise in the world and thus, education was the key to fame and fortune. Education is still regarded as the key to success by modern Koreans.

With the official adoption of Confucian philosophy and the examination system, education became a major social activity throughout the Choson Dynasty

\footnotetext{
${ }^{14}$ The Confucian classics lay out rules of life and those who follow these rules are highly regarded as the educated group. One can say that it is somewhat analogous to the Bible for Christians.
} 
(1392-1910). These social activities of learning evolved around state schools such as the Confucian University (songgyun'gwan) or private academies (sowon) run by individual scholars and ex-officials. Hence, Koreans often consider formal schooling and education to be interchangeable. On the other hand, any vocational education related to three other Castes (Nong, Gong, Sang) are not regarded as high as formal schooling. Even the Ministry of Education and Human Resources Development (former Ministry of Education) refers education as formal schooling in most cases.

Another driving force towards formal education in Korea is the community sense, i.e. conformity society. Macdonald (1990) points out that part of the role of the Korean family and community has been taken over by groupings based on common local origin, common school experience, and common workplace. People within such groups have a strong sense of shared identity and mutual responsibility. Hence, a certain level of formal education is essential for Koreans to remain in such groups. Another useful approach is a model of observational behaviour by Bikhchandani et al. (1998), which agrees with most conformity research results. They claim people learn from the behaviour of others and therefore conform. Naylor (1989) also uses a similar approach of individual behaviour of a social custom to explain the reason why workers strike. Hence, the education in Korea cannot be explained without the influence of Confucianism (culture) as well as conformity (society), which made Koreans place high value on education and respect the educated, considering adoption of a new technology as a part of education for new skills.

Rogers (1995) considers the nature of the social system as one of the five variables determining the rate of adoption. For instance, the Korean Government clearly signalled the network technology as the key for the future via various stages of Government-led technology projects. ${ }^{15}$ Table 5 illustrates the 4 stage technology projects since 1987. The first Korean Backbone Computer Network project (19871992) facilitated the distribution and use of personal computers followed by the second project (1992-1996), which promoted more powerful personal computers and versatile applications including internet communications. This second project

\footnotetext{
${ }^{15}$ The Ministry of Information and Communication has been in charge of these projects since 1987.
} 
benefited from a parallel project launched in 1995, called the High-speed National Information Infrastructure project as it established a public high-speed cable network. This parallel project was designed to provide a favourable environment in delivering multimedia services across the nation. Currently, Korea is undergoing the second stage of this parallel project, namely the Cyber-Korea 21 project (1998-2002). The Government has been reinforcing the nationwide communication network system and its applications to build a knowledge-based information society. The Government budget of 28 trillion won (approx. 20 billion US dollars) was set for the Cyber-Korea 21 project to increase the information infrastructure by 100 times and educate people across the nation.

Table 5 Technology Projects in Korea since 1987

\begin{tabular}{lll}
\hline Year & Project & Objective \\
\hline $1987-1992$ & $\begin{array}{l}1^{\text {st }} \text { Korean Backbone Computer } \\
\text { Network project }\end{array}$ & $\begin{array}{l}\text { To establish the basic infrastructure } \\
\text { for computer network focusing on } \\
\text { distribution and use of personal } \\
\text { computers. }\end{array}$ \\
\hline $1992-1996$ & $\begin{array}{l}2^{\text {nd }} \text { Korean Backbone Computer } \\
\text { Network project }\end{array}$ & $\begin{array}{l}\text { To promote more powerful computers } \\
\text { and diverse applications. }\end{array}$ \\
\hline $1995-1998$ & $\begin{array}{l}1^{\text {st }} \text { High-speed National } \\
\text { Information Infrastructure project }\end{array}$ & $\begin{array}{l}\text { To build a high-speed cable network } \\
\text { nationwide to facilitate the network } \\
\text { communication. }\end{array}$ \\
& Cyber-Korea 21 project & $\begin{array}{l}\text { To build a knowledge-based } \\
\text { information society facilitating the } \\
\text { 100 times of information } \\
\text { infrastructure within the 5 years. }\end{array}$ \\
\hline $1998-2002$ & (2nd High-speed National & \\
& Information Infrastructure project) &
\end{tabular}

The pro-technology policy by the Government certainly encouraged general public to adopt new technologies including the internet. ${ }^{16}$ Not only the Government campaign set a clear social objective regarding the new technology of internet, but also it took the initiative in adopting and implementing the internet technology nationwide. For instance, most civil service documents have been distributed and communicated via the internet since July 2000. Over two decades, the Government 
technology projects have established a new social norm, computer and internetliteracy. It seems natural that Koreans worry about being left behind in the information society and that therefore adopt the new technology sooner rather than later to remain in the respective groups.

\section{Econometric Models}

In order to test the following propositions, a set of econometric models in both static and dynamic set-up are used and compared. For a static version of maximum likelihood estimation, I apply a logistic distribution to test the probability of internet banking adoption as a point estimate at the end of 2001. On the other hand, I use a duration model in order to detect the dynamics of IB adoption process. ${ }^{17}$ The latter approach is useful in identifying the determinants of early adopters versus delayed adopters as the data now contain the sequential information of adoption time.

Proposition 1: individual characteristics affect their behaviour of internet banking adoption (static).

Firm characteristics have often been used for determining firms' technology adoption behaviour in the literature. For similar reasons, I suggest individual characteristics would affect their internet banking adoption.

Proposition 1.1: males are more likely to adopt internet banking than females.

Internet banking requires a minimum level of proficiency in computer skills and internet communication. Thus, I expect that males are more likely to adopt internet banking given that they tend to be more tech-savvy as the International Data Corporation report (IDC, 2002) suggested. ${ }^{18}$

\footnotetext{
${ }^{16}$ The Times (1 Dec. 2004 UK) reported, "South Korea is the most geeky, tech-savvy country almost anywhere and about $73 \%$ households have high-speed broadband."

${ }_{17}$ Duration analysis is often called as Survival analysis or failure time analysis.

${ }^{18}$ IDC has an extensive global network of consultancy on technology information and reports up-todate facts in the industry. Their report (2002) about adoption of wireless communication confirmed that young (average 28 years old) male group are more likely to adopt earlier.
} 
Proposition 1.2: younger generations are more likely to adopt internet banking than older generations.

One way to look at the age factor is younger generations are more likely to adopt internet banking due to their familiarity with contemporary network technology. Some might argue otherwise that Asian countries, including Korea, are obsessed with learning of new technologies and thus, the age factor might not be significant. According to Rogers (1995)' survey on diffusion publications show that more than half of the publications find the age factor as not significant.

Proposition 1.3: people with higher education (university or above) are more likely to adopt IB than those with less education.

Having said that the proficiency in computer technology and network communications would have a positive impact on internet banking adoption, education would enhance the proficiency in network technology and thus would increase the probability of IB adoption. University or above level of education is critical as universities in Korea are heavily relying on internet communication for their foundation of educational system. This argument applies to across different degree majors regardless of art or music degrees. Exposure to a university network system is more important than anything else.

Proposition 1.4: married people are less likely to adopt internet banking than single individuals or those with alternative marital status e.g. separated or divorced.

I consider that married people are relatively conservative compared to those who choose alternative marital status, e.g.. divorced, separated, co-habit, or single. Choice of alternative marital status would have a positive effect on their tendency to try out new technologies as they tend to be less risk-adverse. ${ }^{19}$

\footnotetext{
${ }^{19}$ One could argue that single individuals are also risk adverse by postponing or opting out of marriage but in trying out new technologies, we expect them to be more open-minded.
} 
Proposition 1.5: High-income group is more likely to adopt internet banking than low-income group.

I expect that banking intensity of high-income group would be higher than lowincome group would and hence expect the incentive of IB adoption is larger for highincome group.

Proposition 1.6: residential property owners are less likely to adopt internet banking.

Outright owners of residential properties are less likely to have complex banking than those who are in key money or monthly rental schemes as they do not have to deal with mortgages or monthly payments and therefore, would have less incentive to adopt internet banking.

Proposition 1.7: residents in Seoul and Kyungki metropolitan area are more likely to adopt internet banking than those who reside in regional provinces.

This proposition is based on stronger epidemic effects in the metropolitan area than the remote regions. I also expect that the easier access to computers and internet facilities in the metropolitan area, which would provide better grounds for people to adopt internet banking.

Proposition 1.8: those who were exposed to internet banking recommendations are more likely to adopt internet banking.

This proposition is also applying epidemic effects as I argue those who are exposed to the risk of internet banking via recommendation are more likely to adopt than those who are not yet exposed to recommendation.

Proposition 1.9: those who are aware of interest rate information in the market are more likely to adopt internet banking. 
The reasoning for this proposition is that those who are active information seekers would benefit more from internet banking as they can search around for the best services and products without going to individual bank branches. Hence, they have more incentive to adopt internet banking.

Proposition 1.10: frequent visitors to bank branches are more likely to adopt internet banking.

Those who visit bank branches (OTC) frequently are considered to be keen customers and have more incentive to adopt internet banking as they can save the time travelling to the branches. There might be some customers who prefer more human contact but I expect this preference can be outweighed by substantially lower transaction fees and new services, e.g. enhanced information search facility and live-time financial portfolio management services, offered via the internet when banks aim to substitute most of branch activities with internet banking.

Proposition 1.11: frequent visitors to banks' websites are more likely to adopt internet banking.

The more visits to banks' websites customers make, the greater the chance they would adopt internet banking as the banks advertise various services and benefits of internet banking on the web. Once again, the epidemic effects can be applied in explaining this proposition. The more customers exposed to internet banking information, the higher the probability they would adopt it.

Proposition 2: the determinants of IB adoption timing (dynamic) would differ from those of IB adoption probability (static).

Although I expect that the overall level of IB adoption would vary depending upon individual characteristics, I claim that the adoption timing would also vary among individuals with different characteristics. For instance, not only do I expect males to be more likely IB adopters, but I believe they are more likely early adopters. 
Proposition 3: the first mover (bank) would not increase its market share, i.e. no order effects.

Since the technology of internet banking is not exclusive to the first mover, I am bound to see some spillovers within the industry and would not see significant impact on the first mover's market position. Consumers being cautious about their banking, the first mover would not necessarily capture early adopters.

Proposition 4: the largest bank would increase its market share via internet banking, i.e. rank effects.

I expect customers to prefer banking with a larger bank, which has a wide customer network as they believe the larger the better, i.e. network effects. Traditionally, large banks have been perceived as better banks in Korea and in addition, the network effects of internet banking would reinforce the perception of bank size. Therefore, the largest bank is expected to benefit more from internet banking by capturing early adopters.

Proposition 5: the duration dependence is likely to be positive.

The hazard associated with internet banking adoption is expected to increase with time since customers are exposed to more IB adopters. The epidemic effects can be applied to this proposition. In the same context, the law of imitation can be also borrowed from sociology to support the argument. The forefather of the diffusion studies, Tarde (1903) observed certain patterns of innovation diffusion called the laws of imitation (Les Lois de l'imitation), which we today call the adoption of an innovation. People are more likely to adopt internet banking with the increasing number of IB users as they have more chance to imitate other users as time goes by. 
Proposition 6: the determinants of non-users' future IB adoption would differ from those of IB users'.

For IB non-users who have delayed the adoption of internet banking, I assume that their individual characteristics differ from those of IB adopters. I argue that factors affect non-IB users to adopt IB in the future would differ from those for the current IB users.

First, I use the fully non-parametric duration model to determine the shape of the survival function as well as the hazard function. ${ }^{20}$ The Kaplan-Meier $(1958)^{21}$ survival estimate indicates the IB adoption follows a S-shaped curve considering the data are right censored for non-IB users. ${ }^{22}$ This agrees with the results from most technology diffusion literature. ${ }^{23}$ On the other hand, the hazard function shows a nonlinear monotonic increase in time, more precisely increasing with oscillation. In order to capture this increasing hazard over time, I chose a Weibull distribution, as shown in Figure 6 and 8, for the underlying hazard function of duration analysis and compared three different specifications: 1/continuous time Weibull model (parametric), 2/discrete time proportional hazard $(\mathrm{PH})$ model with Weibull baseline hazard (parametric) and 3/ discrete time proportional hazard $(\mathrm{PH})$ model with flexible baseline hazard (semi-parametric with non-parametric baseline hazard).

The Weibull distribution is one of the most widely used survival distribution. It is a versatile distribution that can take on the characteristics of other types of distributions, based on the value of the shape parameter $p$. The Weibull probability density function can be written with one to three parameters (e.g. scale parameter $\eta$, shape parameter $\mathrm{p}$, location parameter $\gamma$ ) and the density function can have a flexible

\footnotetext{
${ }^{20}$ Kalbfleisch and Prentice (1980) suggest a non-parametric duration analysis has an advantage of not imposing any restriction on the underlying hazard but there are theoretic difficulties in interpreting nonparametric maximum likelihood estimate. Thus, alternative specifications were chosen for the analysis. ${ }^{21}$ Despite the incompleteness of the data, Kaplan-Meier (1958) use the product-limit estimate to derive the proportion of events in the population whose lifetime would exceed $t$, without making any assumption about the form of the probability function.

${ }^{22}$ Figure 3.5 illustrates the $\mathrm{S}$-shaped diffusion path from the Kaplan-Meier estimation.

${ }^{23}$ The evidence of a S-shaped diffusion of technology can be found in Davis (1976), Stoneman and Battisti (2000) and many others.
} 
form depending on these parameters. ${ }^{24}$ The most commonly used density function for duration model takes the two parameter form with scale and shape, but $\gamma=0$ :

$$
f(t)=\frac{p}{\eta}\left(\frac{t-\gamma}{\eta}\right)^{p-1} \cdot e^{-\left(\frac{t-\gamma}{\eta}\right)^{p}}
$$

where most duration literature denotes the hazard rate $\lambda=\frac{1}{\eta}$.

Therefore, the hazard function with Weibull distribution is

$$
\lambda(t)=\lambda p(\lambda t)^{p-1}
$$

and the survival function is

$$
S(t)=e^{-(\lambda t)^{p}}
$$

The Weibull distribution is suitable for a model where hazard rate increases or decreases monotonically since it parameterises the exponential term with $p$ - 1 where $p>1$ can be used for increasing hazard rate, whilst $p<1$ can be used for decreasing hazard rate. The special case of $p=1$ converges to an exponential model in which the hazard rate is constant over time.

\subsection{Logit specification}

With respect to individual characteristics, it is relatively simple to apply a logit specification to the probability of IB adoption as well as to interpret the estimates. Binary choice model has a non-linear probability distribution. Hence I rewrite the cumulative probability function in a logistic form as shown in equation (4).

$$
\text { Cumulative probability: } P_{i}=F\left(z_{i}\right)=\frac{1}{1+e^{-z_{i}}}
$$

\footnotetext{
${ }^{24}$ For further details of the probability distribution, see Kiefer (1988), Spiegel (1992) and Greene (2003).
} 
where $Z=\beta^{\prime} X+u$

Probability at $\mathrm{Z}_{\mathrm{i}}: f\left(z_{i}\right)=\frac{d P}{d z}=\frac{e^{-z}}{\left(1+e^{-z}\right)^{2}}$

Marginal Effects: $\frac{\partial P}{\partial X_{i}}=\frac{\partial P}{\partial z} \cdot \frac{\partial z}{\partial X_{i}}=\frac{e^{-z}}{\left(1+e^{-z}\right)^{2}} \cdot \beta_{i}$

This logit model specification is used for adoption probability for the pooled sample and for non-users' future adoption behaviour. The future adoption behaviour of nonadopters was also investigated by using logit and conditional logit specifications. Equation (4) is the cumulative probability distribution where $Z$ is the individual characteristics function. ${ }^{25}$ As $Z$ tends to infinity, $e^{-z}$ tends to 0 and the cumulative probability has a limiting upper bound of 1 . As $Z$ tends to minus infinity, $e^{-z}$ tends to infinity and the cumulative probability has a limiting lower bound of 0 . Hence the equation (4) is bounded between 0 and 1 . The marginal effect of $Z$ on the probability which will be denoted $f(Z)$ is given by the derivative of $F(Z)$ with respect to $Z$ (equation 5). Equation (6) indicates the marginal effects for each variable.

\subsection{Duration Model Specification}

We are interested in the length of time that elapses before customers adopt a new banking technology (internet banking). I estimate a hazard rate i.e. the conditional probability of an adoption in each month given that the customer has not adopted IB by that time.

The duration to adoption of internet banking was defined as follows: I set the time origin at Jan. 1998 and thereafter, a monthly time scale was set in sequence. The choice of a monthly time scale is due to the nature of survey data. I define the event ending the duration as the first use of internet banking, i.e. IB adoption. Different individuals may have different time origins but my specification assumes everyone

\footnotetext{
${ }^{25}$ Note $Z$ function for individual characteristics here has nothing to do with the z-statistics reported in logit and duration model estimations.
} 
was already exposed to the news of IB introduction prior to the actual introduction of IB. $^{26}$

\subsubsection{Continuous Time Parametric Duration Model (Weibull)}

Parametric specification assigns a certain type of distribution on the hazard function, a Weibull distribution in this paper. It is relatively easy and straightforward to apply this specification but the choice of hazard function is extremely important. Various distributions including exponential, lognormal and log-logistics were tested and the Weibull distribution was chosen, as its log-likelihood is higher than those of other specifications as shown in the table below.

Table 6 Survival Distributions: $\log$-likelihood ${ }^{27}$

\begin{tabular}{lllc}
\hline Distribution & Hazard Function, $\lambda(t)$ & Survival Function, $S(t)$ & $\begin{array}{l}\text { Log } \\
\text { Likelihood }\end{array}$ \\
\hline Exponential & $\lambda$ & $S(t)=e^{-\lambda t}$ & -313.63 \\
Weibull & $\lambda p(\lambda t)^{p-1}$ & $S(t)=e^{-(\lambda t)^{p}}$ & -263.55 \\
Lognormal $^{28}$ & $f(t)=(p / t) \phi[p \ln (\lambda t)]$ & $S(t)=\phi[-p \ln (\lambda t)]$ & -337.76 \\
Log-logistic $^{29}$ & $\lambda(t)=\lambda p(\lambda t)^{p-1} /\left[1+(\lambda t)^{p}\right]$ & $S(t)=1 /\left[1+(\lambda t)^{p}\right]$ & -312.11 \\
\hline
\end{tabular}

In addition, the survival function and hazard function seem to fit the non-parametric specification results best. Finally, the time interval is assumed to be small enough to apply continuous time. The Weibull model is specified as: ${ }^{30}$

\footnotetext{
${ }^{26}$ Davies (1979) claims no potential adopter is prevented from adopting by total ignorance or patent restrictions when potential adopters in the industry are assumed to know of the existence of the innovation once it is first commercially available.

${ }^{27}$ For further details of each distribution, see Kiefer (1988) and Greene (2003).

${ }^{28} \ln (\mathrm{t})$ is normally distributed with mean $-\ln (\lambda)$ and standard deviation $1 / p$.

${ }^{29} \ln (\mathrm{t})$ has a $\log$-logistic distribution with mean $-\ln (\lambda)$ and variance $\pi^{2} /\left(3 \mathrm{p}^{2}\right)$.

${ }^{30}$ Let $\mathrm{T}$ be the length of a complete spell and $\mathrm{t}$ is a random time variable with a cumulative distribution function of $F(t)$ and probability density function of $f(t)$. Therefore, the diffusion of IB adoption is represented in the failure function, which is $1-S(t)$. If the ancillary parameter, $p>1$, the hazard rate rises monotonically with time and falls if $p<1$.
} 
Hazard function(Weibull):

$$
\begin{aligned}
\lambda(t) & =\lim _{\Delta \rightarrow 0} \frac{\operatorname{Prob}(t \leq T \leq t+\Delta \mid T \geq t)}{\Delta}=\lim _{\Delta \rightarrow 0} \frac{F(t+\Delta)-F(t)}{\Delta S(t)} \\
& =\frac{f(t)}{S(t)}=\lambda p(\lambda t)^{p-1}
\end{aligned}
$$

Probability density function:

$f(t)=\lambda p(\lambda t)^{p-1} \cdot S(t)=\lambda p(\lambda t)^{p-1} \cdot e^{-(\lambda t)^{p}}$

Survivor function: $S(t)=\operatorname{Pr}(T>t)=1-F(t)=e^{-(\lambda t)^{p}}$

Failure function: $F(t)=\operatorname{Pr}(T \leq t)=1-S(t)$

where $\lambda \equiv \exp \left(\beta^{\prime} X\right)$

The hazard rate, $\lambda(t)$ is the conditional probability of having a spell length exactly $t$, i.e. adopting IB in interval $[t, t+\Delta t]$, conditional on survival up to time $t$. The equation (7) shows the hazard function is a limiting case of conditional probability of event. But the hazard rate is not a probability in a pure sense since it can be greater than 1. The Weibull distribution allows the hazard rate for an individual to change monotonically. In the case of IB diffusion, I expect to see positive duration dependence $(p>1)$. I derive the hazard function by conditioning on survival up to time $t$ and write the survival function as in equation (9). Then, the failure function takes the form, $1-S(t)$ as in equation (10).

\subsubsection{Discrete Time Proportional Hazard (PH) duration Model (with parametric} baseline hazard)

A discrete time duration model is appropriate as my data set observations are made in discrete time, i.e. adoption in monthly intervals, although the intrinsic nature of the IB adoption is in continuous time. I chose a complementary log-logistic (cloglog) hazard function over a logistic one as the adoption process of internet banking is intrinsically 
continuous but only the observations are in discrete time. In principle this specification is an extended version of Cox proportional hazard model as illustrated in Kiefer (1988) for discrete data analysis. ${ }^{31}$

$$
\begin{aligned}
& \text { Hazard Function: } \lambda_{i t}=\lambda_{0}(t) \cdot \exp \left(X_{i t}{ }^{\prime} \beta\right) \\
& S\left(t ; X_{i t}\right)=\exp \left[-\int_{0}^{t} \lambda\left(\tau ; X_{i t}\right) d \tau\right]=\exp \left\{-\exp \left[X_{i t}{ }^{\prime} \beta+\log \left(H_{t}\right)\right]\right\}
\end{aligned}
$$

where $H_{t}=-\int_{0}^{t} \lambda_{0}(\tau) d \tau$ and $\lambda_{0}(t)$ is the baseline hazard at $t$

The hazard function (equation 11) takes a proportional form assuming that for some unknown $\beta$ and some nonnegative measurable function $\lambda_{0}(t)$, the baseline hazard at time $t$. Subject to a complementary log-logistic transformation for the discrete time, the survival function can be written as equation (12).

With censoring $c_{i}=0$ for those who are not yet adopters, the log-likelihood can be written as:

$$
\begin{aligned}
& \log L(\beta, \delta)=\sum_{i=1}^{n}\left\{c_{i} \log \left[S\left(t_{i}-1 ; X_{i t}\right)-S\left(t_{i} ; X_{i t}\right)\right]-\left(1-c_{i}\right) \log S\left(t_{i} ; X_{i t}\right)\right\} \\
& \text { where } \delta=\log (H) \\
& \log L=\sum_{i=1}^{n}\left\{c_{i} \log \left\{\lambda_{i t}\left(X_{i t}\right) \prod_{s=1}^{t_{i}-1}\left[1-\lambda_{s}\left(X_{i s}\right)\right]\right\}+\left(1-c_{i}\right) \log \left\{\prod_{s=1}^{t_{i}}\left[1-\lambda_{s}\left(X_{i s}\right)\right]\right\}\right\}
\end{aligned}
$$

\footnotetext{
${ }^{31}$ Kiefer (1988) provides a comprehensive list of survivor, probability distribution and hazard functions, which is useful at a starting point of duration analysis. However, Lancaster (1990) discusses transition data most thoroughly with a focus on duration data analysis.
} 
where the discrete time hazard is

$\lambda_{t}\left(X_{i t}\right)=1-\exp \left[-\exp \left(X_{i t}{ }^{\prime} \beta+\gamma_{t}\right)\right]$

with $\gamma_{t}=\log \int_{a_{t-1}}^{a_{t}} \lambda_{0}(\tau) d \tau$

The log likelihood function in equation (13) shows the weighted average form of maximum likelihood from both censored and uncensored groups. The first half of the equation represents the likelihood of an exit (i.e. IB adoption) at time $t$, thus a product of all the previous periods' survival likelihood, whereas the second half of the equation illustrates the case of non-exit. The equation is simply weighted by $c_{i}$ and 1$c_{i}$ for that matter: $c_{i}=0$ for censored group and $c_{i}=1$ for uncensored group. The hazard function with a complementary log-logistic transformation for the discrete time is shown in equation (15).

\subsubsection{Discrete Time Proportional Hazard (PH) Duration Model (semi- parametric with flexible baseline hazard)}

By adding duration dummy variables for each interval to the above specification, a semi-parametric estimation is also feasible. The advantage of using a semi-parametric specification is that I do not impose any assumption on the baseline hazard function and allow it to be fully flexible. In principle, this model calculates hazard rate for each interval under no restriction. Given the advantage of flexible baseline hazard function and the nature of my data being discrete in time, this model specification is preferred to others. However, I expect to see similar results from all three specifications despite the different underlying assumptions.

\subsubsection{Unobserved heterogeneity in duration Model}

The estimation in the presence of unobserved individual specific effects (i.e. heterogeneity) without control causes misleading inferences due to inconsistent parameter estimators (Lancaster, 1990). If there are other (unobserved) characteristics that influence the hazard function, such omitted heterogeneity generally leads to a downward biased estimate of duration dependence (Kiefer, 1988). The above duration 
models can be extended for this purpose by including a random error term along with the vector of individual characteristics $X$ (i.e. use $X^{\prime} \beta+v$ ). A most commonly used correction model is based on the gamma distribution with mean 1 and variance $\theta$. The gamma distribution and the inverse Gaussian distribution are often used for the heterogeneity distribution in parametric duration models since they give a closed form expression for the likelihood, avoiding numerical integration. However, other distributions could in principle be used (see Meyer, 1990). By incorporating heterogeneity into the distribution, I get the conditional survival function for the Weibull model specified as

$$
S(t \mid v)=v \cdot e^{(-\lambda t)^{p}}
$$

Thus, the unconditional survival function is

$$
S(t)=\left(1+\theta(\lambda t)^{p}\right)^{-1 / \theta}
$$

and the hazard function is

$$
\lambda(t)=\lambda p(\lambda t)^{p-1} \cdot(S(t))^{\theta}
$$

where $\theta=0$ corresponds to the model without unobserved heterogeneity and the further $\theta$ deviates from zero, the greater is the effect of heterogeneity. For simplicity of the estimation, a normal distribution of heterogeneity for the complementary loglogistic model is used for the proportional hazard models. However, we fail to reject the null hypothesis of no heterogeneity for all three duration models. Therefore, the mixed models with unobservables converge to the models without unobservables. Only the results from models without unobservables are presented. 


\subsection{The Data}

Yahoo Members' Directory ${ }^{32}$ was used to collect email addresses of Korean residents with age 13 or above, applying a systematic and stratified sampling. ${ }^{33}$ The online survey forms were sent out via email requests to 3200 addresses, of which 407 responded after two follow-ups. ${ }^{34}$ In total, 393 replies were used in the analysis having discarded duplicates or incomplete replies. A random sampling of the population was not used as our research focus lies in those who already have access to the internet. However, one should note that the above systematic and stratified sampling of the internet users would capture more meaningful results for our research purpose. More importantly, a significantly large proportion of the population in Korea uses internet. A recent survey conducted by the National Internet Development Agency (NIDA) commissioned by the Ministry of Information and Communications (MIC) indicates that 31.6 million people are using the internet more than once a month (i.e. $70.2 \%$ of the population). Considering the under age and elderly groups who are not able to and do not want to use the internet, this is a substantially large proportion of the population.

A cross-sectional data set of 393 individuals was used in the static analysis of internet banking adoption and the data were expanded into panel data by assigning binary choice dummies for each monthly interval for the dynamic analysis (duration analysis). The last event was observed in the $48^{\text {th }}$ month (December 2001) from the introduction of Internet Banking (IB) in January 1998. Thus, an unbalanced data set of 6407 observations were obtained, with 246 individuals responding as internet banking users and 147 identified themselves as non-users (right-censored).

\footnotetext{
${ }^{32}$ www.yahoo.co.kr is one of the largest digital media companies in Korea, which provides a variety of information through the internet. Yahoo also offers free email accounts for their members.

${ }^{33}$ The 3200 email addresses were collected across 107 different cities throughout 11 provinces (see Table 7 for the details of stratified sampling). Every $3^{\text {rd }}$ person from Yahoo Members' Directory was selected in proportion to the population density data from the Korea National Statistical Office (systematic sampling). The response rate was at $12.7 \%$, which was below the expected rate of $20 \%$. The expected rate of reply was initially drawn from interviews with local online survey companies in Korea (e.g. www.koreanclick.com and www.internetmetrix.co.kr). The lower response rate seems to be due to the sensitivity of survey questions, e.g. personal banking.

${ }^{34}$ The sampling period is between 13 November, 2001 - 13 February, 2002
} 


\section{Questionnaire:}

Following a pilot survey, an online survey form is constructed. ${ }^{35}$ The questionnaire on internet banking consists of 37 questions. The first section contains 10 questions on demographics. The second section has two parts, 1/aimed at those who used internet banking at least once, identified as a user group (IBU) and 2/for those who have not yet used internet banking, identified as a non-user group (NU). The user group is questioned on IB adoption timing, their banks, internet banking details in terms of average amount of transaction and the frequency. Also commonly used IB services are asked alongside their IB selection criteria. Equivalently, the non-user group is questioned on their reasons for no-adoption and adoption criteria if they plan to use IB in the future. The final section includes questions on information seeking behaviour in banking and their general banking pattern such as length of long-term relationship with the bank, frequency of visit to OTC and banks' web pages. Table 10 shows the outline of the survey questions.

\section{Variables:}

The non-parametric log-rank inequality test and the Wilcoxon test are conducted on potential explanatory variables and the test results are presented in Table 11 for the variables. For example, the Wilcoxon test divides the sample into subgroups and tests the null hypothesis of identical survival function across the subgroups, i.e. $S_{i}(t)=S_{j}(t)$. As the Wilcoxon test gives higher weights to earlier failure times, it is more likely to detect early differences in failure times. On the other hand, the log-rank test is based on scores assigned to the observations, which are functions of the logarithm of survival function. The test statistic is the sum of scores over all observations standardised by standard deviation in this case. The log-rank test gives equal weights to all failures and therefore is more powerful in detecting failures in proportional hazard models, which is the case of this paper. The explanatory variables included in the model are described in Table 9, which are classified in: 1/ demographics; 2/exposure to internet banking; 3/awareness; 4/banking behaviour, and 5/first mover

\footnotetext{
${ }^{35}$ The pilot survey was conducted between 7-28 Mar.2001 targeting 120 residents in Seoul. Out of 120 target residents, 99 responded and these were used in the preliminary analysis. However, the online survey allowed me to reach 3200 Korean residents over the internet without any geographical distance.
} 
and largest bank dummies. The summary statistics of the variables are presented in Table 11.

\section{Results}

\subsection{Descriptive Statistics of the Sample}

Before presenting results from the probability and duration models of the adoption process, we examine some simple descriptive statistics. Table 11 reports means and standard deviations of the key variables used in the analysis. It is worth noting that the research interest of this paper does not lie in the entire population in Korea but in those who have access to the internet. Considering the nature of technology involved with internet banking itself and the random online survey of the internet user population, the high proportion of male group (i.e. $69.2 \%$ is $S e x=1$ ) responses seems to be right and this coincides with the report by the International Data Corporation (IDC, 2002) on web users in Asia, of which the $64 \%$ are male.

The survey takes 7 different levels of final educational attainment. However, only a grouped dummy for higher education $(E d u)$, i.e. university or above is used in the analysis in order to minimise the loss in degree of freedom by having too many insignificant variables suggested by the non-parametric tests (log-rank and Wilcoxon). A very high proportion $(84.7 \%)$ indicated educational attainment of university or above with little variation. However, it is not surprising since more than $70 \%$ of the population between 18 and 21 are involved in some form of higher education (end of 2001) with a growing tendency according to the statistical report by the Ministry of Education and Human Resources Development (MOE, 2001). ${ }^{36}$ Given the conditioning on internet access and the banking related questions would possibly explain the relatively high level of education compared to that of the MOE's. One important observation to make is Korea has traditionally favoured higher education in the belief that investment in human capital is the only way to rebuild the country from the aftermath of Korean war. Hence, university education in Korea has become more or less an essential certificate for employment.

\footnotetext{
${ }^{36}$ See http://www.moe.go.kr/ for more details.
} 
Therefore, the education variable needs to be explained by the influence of Confucianism (culture) as well as conformity (society), which made Koreans place high value on education and respect the educated. Education is given a high priority by Koreans from all backgrounds and this has been a major driving force behind Korea's economic development. For instance, the student population is about a quarter of the total population and the average length of schooling is now over 12 years, which means more than high school graduation. This is also reflected in my sample data where we find a high proportion of university graduate or equivalent. Culturally driven efforts into education set higher education as a social norm in Korea. A high proportion with higher education is not because of the sample bias but because of the country specific characteristics regarding education.

The age variable was grouped into three, 1/ young (Agel=13-24), 2/ middle (Age $2=25-44)$, and 3/ old (Age3=45 or above). The majority of people are categorised in 25-44 years old (74.8\%) whereas $15.5 \%$ is in the young group between 13 and 24 years old and $9.7 \%$ is above 45 years old. Although I have classified groups into three for simplicity to obtain more meaningful estimation results, a detailed age breakdown (10-year interval) is compared to the internet user profile of the Korea National Statistical Office (KNSO) data 2000 in Table 8. I notice that the general internet user profile has a more weight on the young teenage group compared to the internet banking survey profile. I expected to see such difference given the nature of the survey on the banking activity. Otherwise, the age profile of the survey sample represents more or less the Korean internet user profile.

More than half of the respondents are married (Marm) whereas $44.5 \%$ indicates as single (Mars) and only $2.5 \%$ indicates as divorced or separated (Maro). Given the cultural background being still conservative, it is not surprising to see no respondents in the co-habit category. On the other hand $2.5 \%$ of non-traditional marital status suggests the society is changing as well. According to the census 2000 data of the Korea National Statistical Office (KNSO), 50\% of the population are married, $23 \%$ are single, $1.8 \%$ are divorced and the rest take other alternative marital status such as separated or co-habiting. The over-representation of the single group 
was expected given the survey sample focused on the internet users only ${ }^{37}$ and covering from the age 13 instead of the KNSO census's 15 and above.

Regarding income levels (Inc0, Inc1 and Inc2), I set the middle range incomers (Incl) around the average personal income of 3 million won per month suggested by the census 2000 data of the KNSO. A small proportion of $4.8 \%$ indicated the income category below 2 million won per month. The majority $(66.2 \%)$ was in the category between 2 million - 4 million won per month while $29 \%$ indicated their income above 4 million won per month.

The housing type dummy (Hsel) shows $61.1 \%$ of the respondents own their housing outright, which closely reflects the KNSO data $(61.87 \%)$ as of 1999 . The residential area dummy indicates (Areal) the $61.6 \%$ of the sample is drawn from the Seoul and Kyungki metropolitan area. This figure is higher than the KNSO data of $46.7 \%$ as of 2001 end based on the district registrar. This can only be explained by the metropolitan population's more favourable attitude towards online surveys since the survey forms were sent out to each province in proportion.

Most respondents had received recommendation $(R c)$ of internet banking $(78.6 \%)$ and a high proportion $(62.6 \%)$, responded as current internet banking users (IB). ${ }^{38}$ Almost half (47.6\%) of non-users (NUs) consider security reasons (riskaversion $)^{39}$ as one of the main obstacles in using internet banking and the second common reason not to use internet banking was because they feel happy with the existing banking services $(37.4 \%$, inertia). Feeling safe with the old technology once again supports the idea of inertia. However, $85.0 \%$ of NUs replied that they would use internet banking in the future (Uplan) and consider the following criteria in order of priority: 1/ reputation of the bank, 2 / lower fees, and 3/user friendly web page.

In terms of banking behaviour, the over-the-counter tellers at bank branches (Otcfr) were visited 2.582 times per month on average whilst banks websites (Ibfr) are visited 5.548 times per month on average. This suggests any regular internet users would visit respective bank websites 1.3 times per week. On the other hand, $17.1 \%$ of

\footnotetext{
${ }^{37}$ The Ministry of Information and Communication (MIC) 2000 report on internet users indicates a higher proportion of singles in the internet user profile.

${ }^{38}$ Pilot test showed most customers are internet banking with their current banks. This suggests that switching banks for better internet banking services rarely happens and consumer inertia exists

${ }^{39}$ Appropriate regulation and technology can prevent IBUs from exposing themselves to risks.
} 
the internet banking users are banking with the first mover bank $(B k l)$ while $40.2 \%$ of the users are banking with the largest bank (Bk6).

\subsection{Logit Result $\left(\operatorname{Pr}\left(y_{i}=1\right)\right)$}

Table 12 looks at probability of having adopted IB and provides the results of logit estimation with the marginal effects. Regarding the proposition 1 in static framework, most demographic variables are insignificant whilst the age dummy for the young group (Agel), exposure to internet banking $(R c)$ and banking behaviour (Ibfr) are significant. The answer as to why demographic variables do not appear as significant as expected, is that the Korean society has a somewhat unique attitude towards new technology. I should probably borrow the imitation concept from sociology (Tarde, 1890) for the insignificant results. It draws attention to the importance of social structural characteristics, which might influence the amount and/or rate of adoption as well as any potential advantage for some segments of the social system in adopting the innovation. I believe this is an important aspect to investigate further, not only for diffusion among consumers but also among firms as the social structure can determine level of welfare increase with the innovation.

For age variables, it strongly indicates the reference group of 45 years old or more is more likely to adopt IB than younger generations between ages 13-24. The age group between 13-24 (Agel) appears to adopt IB significantly less than those in the age group 45 or above (Age3) as banking activities grow larger and more complex as people become older. ${ }^{40}$ Its marginal effect suggests that those who belong to the age group of 13-24 would have the probability of IB adoption lowered by .439 compared to the reference group. The middle age group between 25-44 also indicates less likely to adopt IB than those above 45 years old, although it is not significant. This contradicts the proposition 1.2 and suggests that the age effect on internet banking adoption cannot be assessed solely on tech-savvy grounds but should also consider active banking age groups as banking activities grow larger and more complex as people become older. 
I find evidence that those who have received a recommendation of internet banking and make frequent visits to banks' websites are more likely to adopt internet banking. This result confirms proposition 1.8 and 1.11. These two propositions are related to the epidemic theory of diffusion. More exposure to risk of adoption, i.e. information and advertisement on internet banking, creates higher probability of diffusion.

Most demographic variables are insignificant with the exception of young age group dummy (Agel) but given the join significance test, the signs of the coefficients are noteworthy: Females are marginally more likely to adopt internet banking than males, which disagrees with proposition 1.1. However, given the insignificance, it is not right to draw any firm inference. Older generations are more likely to adopt internet banking unlike our initial expectation. The age effect should be seen in the industry specific context since younger generations' banking activity is relatively limited than that of older ones' despite their tech-savvy behaviour and willingness to adopt new technologies.

People with higher education $(E d u)$ are less likely to adopt internet banking than those with less education, which indicates the cautious behaviour toward internet banking. The result on marital status (Mar) agrees with proposition 1.4. Those with alternative marital status rather than single or married are more likely to adopt the internet banking. Proposition 1.5 on income level (Inc0, Inc1, and Inc2) is proved to be true where high income group is more likely to adopt internet banking than low income group. I can suggest that banking activity tends to increase with income level and thus it creates more incentive to adopt internet banking.

Regarding housing type dummy, the result shows that outright house owners are less likely to adopt internet banking as in proposition 1.6. This might be explained by the fact that outright ownership would actually reduce the complexity of banking. Those who lease the property tend to have more complex financial management in order to arrange loans tied in the key money scheme. ${ }^{41}$

\footnotetext{
${ }^{40}$ The omitted group for age dummies is 45 years old or more (Age3), for marital status dummies is the group for divorced, separated or co-habit (Maro), for personal income dummies is high incomers group (Inc2) of 4 million won per month or above.
} 
The result on the area dummy contradicts proposition 1.7. This can be explained by higher incentives to adopt internet banking for those who are in remote provinces as they can save substantial amount of time when bank branches are not closely located.

The proposition on information seeking behaviour (Irinfo) is supported by the results as well. The number of visits to OTC (Otcfr) affects the likelihood of IB adoption positively although it is marginal and insignificant.

In summarising the results from the binary static model, traditional demographic variables; sex, education, marital status, personal income level, housing type and residential area are not significant for the likelihood of IB adoption with the exception of the age dummy variable. By contrast, the exposure to the new technology $(R c)$ and banking behaviour (Ibfr) play an important role in IB adoption decision. For example, those who received IB recommendation would have the probability of IB adoption increased by 0.265 compared to the non-recommended group, and each additional visit to banks' websites per month would increase the probability of IB adoption by 0.011 .

\section{Duration Models}

Before I compare the results of static and dynamic specifications, it is essential to assess the differences in the results of the respective duration models. The results are similar across models. The parametric Weibull model and proportional hazard model with Weibull baseline are very similar. The non-parametric baseline model seems to detect more significant variables than other models as expected due to the nonparametric approach. Since the discrete-time PH model with non-parametric baseline (i.e. semi-parametric) is more appropriate for our data, not to mention the advantage of having imposed few restrictions, I choose this as the preferred specification.

First, the demographic variables tend to be more significant in the duration model (dynamic) than in the binary choice model of logit (static). The timing of IB

\footnotetext{
${ }^{41}$ The key money scheme in Korea is a unique mechanism. An owner retains his/her ownership rights while the property is leased out to a tenant by a long-term contract. The tenant should put a lump-sum deposit in the owners account so that the owner can earn some interest income from the deposit. The deposit amount varies depending upon the property market condition but usually $50 \%-90 \%$ of the actual property value has to be kept in the owner's bank account for a deposit.
} 
adoption by male is significantly different from that by female, whereby males are more likely to be early adopters. The age dummy for the group between $25-44$ is also significant in decreasing the likelihood of early adoption compared to the reference group of those above 45. This coincides with Rogers (1995) core group claim. Those who are 45 or above are more likely to be early adopters as opposed to other age groups and also the male group is more likely to be early adopters than the female group. The core of banking network in Korea tends to be middle aged or above male since they are the ones who make key financial decisions for the household.

Although insignificant, education affects IB adoption negatively both in logit and duration models. In Table 14, the Weibull model suggests the predicted time of adoption for males is 3.245 month earlier than females at the mean or according to the non-parametric baseline model, the probability of adoption at each discrete time interval increases by 0.01 for males. Regarding the age dummies, the non-parametric baseline model suggests that the age group between 25-44 lowers the probability to adopt IB in each discrete time interval by 0.013 . On the other hand, marital status dummies become more significant with the same negative effects. Singles or married people are less likely to be early adopters than either divorced or separated people. For instance, the probability of IB adoption for singles is lower by 0.02 and that for married people is lower by 0.017 than the reference group of divorced or separated at each discrete time interval. However, personal income dummies remain insignificant in the duration models.

Second, it is worth noting that recommendation of IB affects the likelihood of early adoption negatively. Perhaps early adopters are opinion leaders who act on their own initiatives rather than being persuaded by bank's recommendation. However, information-seeking behaviour remains as a positive impact on the likelihood of early adoption.

Finally, the results on general banking behaviour are substantially different than those from the logit specification. It is strongly suggested that those with less frequent visits to banks' branches and frequent visits to banks' websites are more likely to be early adopters. The Weibull model shows that each additional visit to banks' website per month makes the IB adoption earlier by 0.186 month or 5.58 days while the non-parametric baseline model indicates 0.001 increase in probability for a 
discrete time interval, i.e. a month. The latter marginal effect might appear to be very small but it is equivalent to $2.16 \%$ increase in probability of adoption at the mean probability, which is 0.023 .

All in all, I can conclude that proposition 2 is strongly supported by the above results and say that the determinants of IB adoption timing (dynamic) differ from those of IB adoption probability (static).

In order to detect order effects, whether the first mover (bank) in internet banking actually captures early adopters and improves the bank's market position (market share), a dummy variable of the first mover, Chohung Bank (Bkl) was included. For rank effects, a dummy variable of the largest bank in commercial banking, Kookmin Bank (Bk6) was added. ${ }^{42}$ All three duration models show more or less similar results on these dummies. ${ }^{43}$ The coefficient of order effect dummy is negligible and not significant whilst that of the rank effect dummy is not only large but also significant. In other words, customers of the largest bank tend to adopt earlier than those of smaller banks while customers of the first mover bank are not particularly early adopters.

The discrete duration models suggest that those who are banking with the largest bank (Bk6) increase their probability of IB adoption by 0.007 compared others at mean for the discrete interval as shown in Table 14. This confirms proposition 3 and 4 and suggests that consumers tend to value the size of bank's asset size, i.e. banks' network size measured in market share more than the first mover advantage in the timing of adoption decision.

Having said that early adopters are opinion leaders, the largest bank's market share is expected to rise with internet banking due to the network. Figure 1 supports the result, as the market share of the largest bank $(B k 6)$ in internet banking is more dominant than in commercial banking while that of the first mover $(B k l)$ remains constant. Although I fail to show order effect, significant rank effects provide grounds for banks to take preemptive actions since banks can reinforce their market dominance via internet banking.

\footnotetext{
${ }^{42}$ Kookmin bank (Bk6) has been the largest bank in terms of deposit size since 1995, thus the largest bank over the period of analysis.

${ }^{43}$ Narendranathan and Stewart (1993) have a good example of comparing different duration models where the results are actually similar.
} 
Despite the different duration model specifications, the result on duration dependence is identical and confirms the positive duration dependence expected in proposition 5. The positive parameter estimate of $\mathrm{p}$ in the parametric Weibull model suggests a positive duration dependence as $\mathrm{p}$ is greater than $1(\mathrm{p}=1.888)$. This can be easily detected in the proportional hazard model with parametric Weibull baseline, as the coefficient of $\log ($ time$)$ is positive and significant. The non-parametric baseline model also suggests the same positive duration dependence as the coefficients of time duration dummies are increasing from more negative numbers to less negative numbers.

\section{Internet Banking Non-Users (NU)}

Finally, I analyse the characteristics of IB non-users (NU) regarding their future IB adoption and see how they differ from the adoption of the current IB users. Table 15 provides a static comparison of the following three specifications: $1 /$ the probability of IB adoption on the full sample (Model 1); 2/ the non-users' probability of future IB adoption (Model 2), and 3/ the conditional probability of future IB adoption having not adopted (Model 3). The simple logit estimation discussed earlier in section 5.2 is used as our benchmark specification of Model 1. On the other hand, Model 2 characterises the probability of future IB adoption (Uplan) based on a simple logit estimation. I estimate Models 2 and 3 on the sub-sample of 147 individuals who did not adopt IB as of 2001 end. Model 3 is a modification of Model 2 using a conditional logit estimation for future IB adoption conditioning on current non-adoption. The results from Model 2 and 3 are extremely similar except that the conditional logit (Model 3) provides less significant results given the small number of observations for non-IB users (NU). One noticeable difference among the three models is that age dummies are not significant for non-users' future adoption decision and the residential area is now a significant factor. It strongly suggests that non-users who reside in the Seoul metropolitan area are more likely to adopt internet banking in the future. Again, the epidemic effects can explain this result. The variables such as recommendation $(R c)$ and frequency of visits to bank's website (Ibfr) remain as significant for nonusers as well. For instance, each additional visit to banks' website increases nonusers' probability of future adoption by 0.014 at mean. 
It is difficult to test the notion of consumer inertia and risk aversion directly from the above 3 models. However, it can be deduced indirectly by the fact that the reasons not to adopt IB (i.e. delayed IB adoption) are being happy with the existing banking methods (inertia) and the concerns over uncertain security (risk-aversion). This is where public policy has to intervene to optimise the adoption path of internet banking. When consumers face unidentifiable amount of risks associated with internet banking such as human errors in inputting data on the web or security breakdown on personal information protection, the public policy should intervene to reduce the potential welfare loss associated with such inefficient early adoptions.

We are living in a society increasingly reliant on the internet. However, unfortunately the internet is largely unregulated and anyone from anywhere in the world can set up shops and offer products and services through the internet. The analyses and the discussion in this paper only focus on the adoption of internet banking but the lessons from the Korean internet banking and the government policies regarding internet banking and general technology shed some light to research on new industries and markets using internet technology.

On the other hand, when consumers are delaying their adoption simply due to inertia despite the substantial benefits of new technology, the public policy should now encourage the adoption to increase the social welfare. Hence, an appropriate balance between the above policies is desirable for an optimal technology adoption path.

\section{Conclusions}

The results presented in this paper provide strong evidence that a probability of internet banking adoption and its duration is affected by individual characteristics. The individual characteristics include, demographics, the exposure to the hazard, information seeking behaviour and general banking behaviour. Moreover, the demographics are less important than banking-specific behaviour for the probability of a new banking technology adoption whilst they are equally important in the duration models.

The results also suggest that rank effects of banks have significant impact on customers' adoption timing of internet banking whilst order effects of banks are 
negligible. Hence, aggressive expansion in internet banking by dominant banks may be justified by the notion of pre-emption.

By contrast, duration dependence is a significant factor when a society is driven by a social norm, i.e. the adoption of internet banking. The social behaviour of East Asian countries is often represented by conformity and imitation based on the Confucian tradition. This unique social structure of Korea has driven Koreans to act collectively rather then individually and this is why the country is experiencing such rapid diffusion of internet banking across banks as well as consumers.

In establishing the social norm of internet banking, the Government plays a significant role by narrowing the socio-economic gaps. Internet banking seems to be a national phenomenon in Korea where favourable behaviour towards new technology of a country outweighs individual characteristics. This is why I do not find significantly different results in the adoption process regarding many of the demographic variables.

Finally, the analysis provides evidence on the possible consumer inertia and risk-aversion when a new banking technology is introduced as non-IB users identify their reasons to delay the adoption as being happy with the existing banking methods (inertia) and the aspects of uncertain security (risk-aversion).

If the security issue is one of the main concerns for both adopters and nonadopters, appropriate public policy and regulation are required to mitigate the potential loss of welfare in case of financial accidents on the internet as well as to optimise the speed of adoption.

This paper focuses on Korean internet banking in particular by drawing attention to aspects of social structure concerning education and technology. However, given that Korea has the highest IB penetration ratio in the world, I believe the empirical evidence of this study will add some value to those who are involved with internet banking in other countries. 


\section{Appendix}

Figure 1 Market Share: Commercial Banking vs. Internet Banking ${ }^{44}$

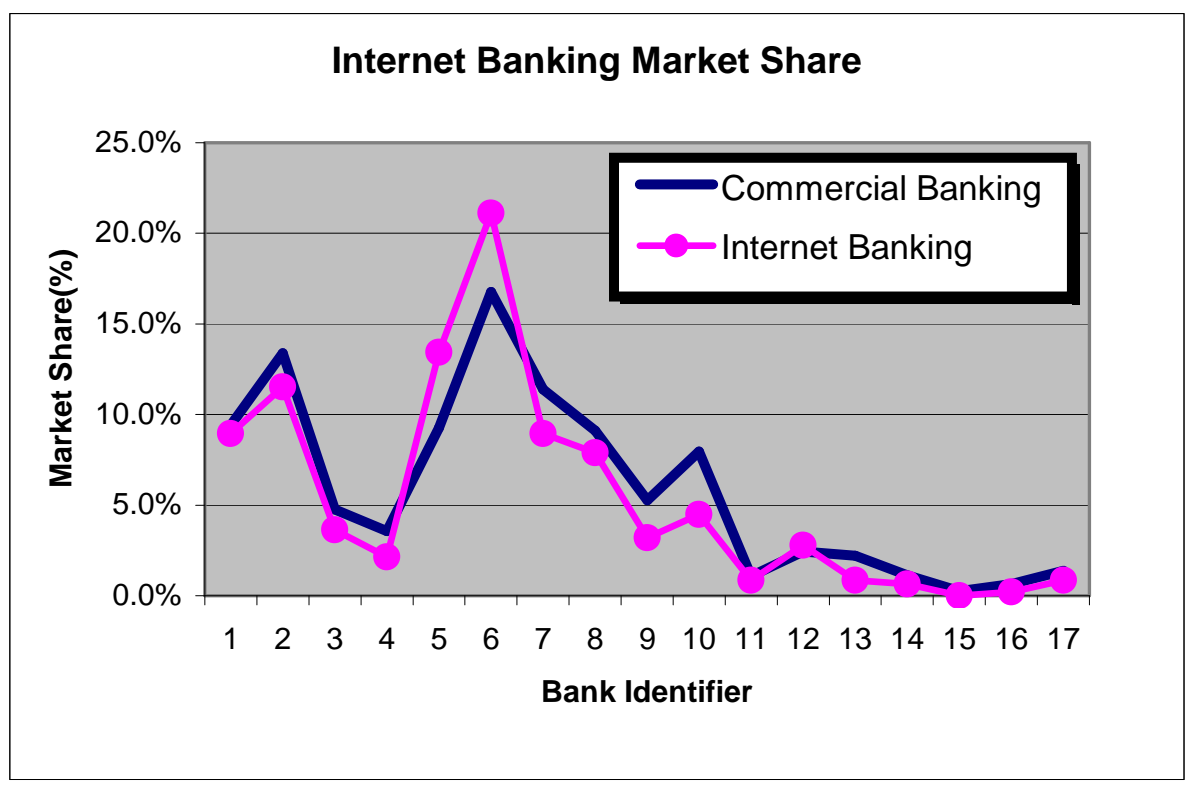

Figure 2 Internet Banking (IB) Adoption per Month

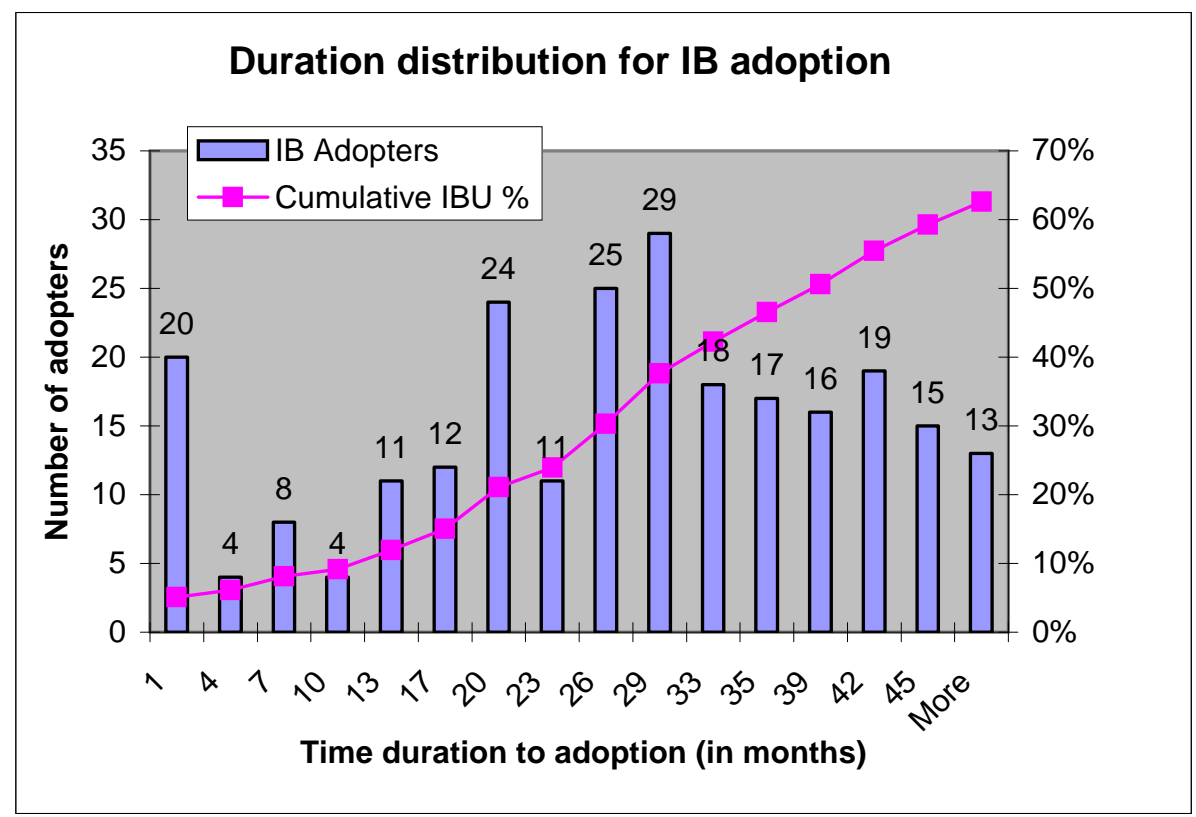

\footnotetext{
${ }^{44}$ The market share in commercial banking is in terms of asset size at the end of 2001 and that in internet banking is based on the survey data.
} 
Figure 3 Number of Registered Internet Banking Users (IBUs)

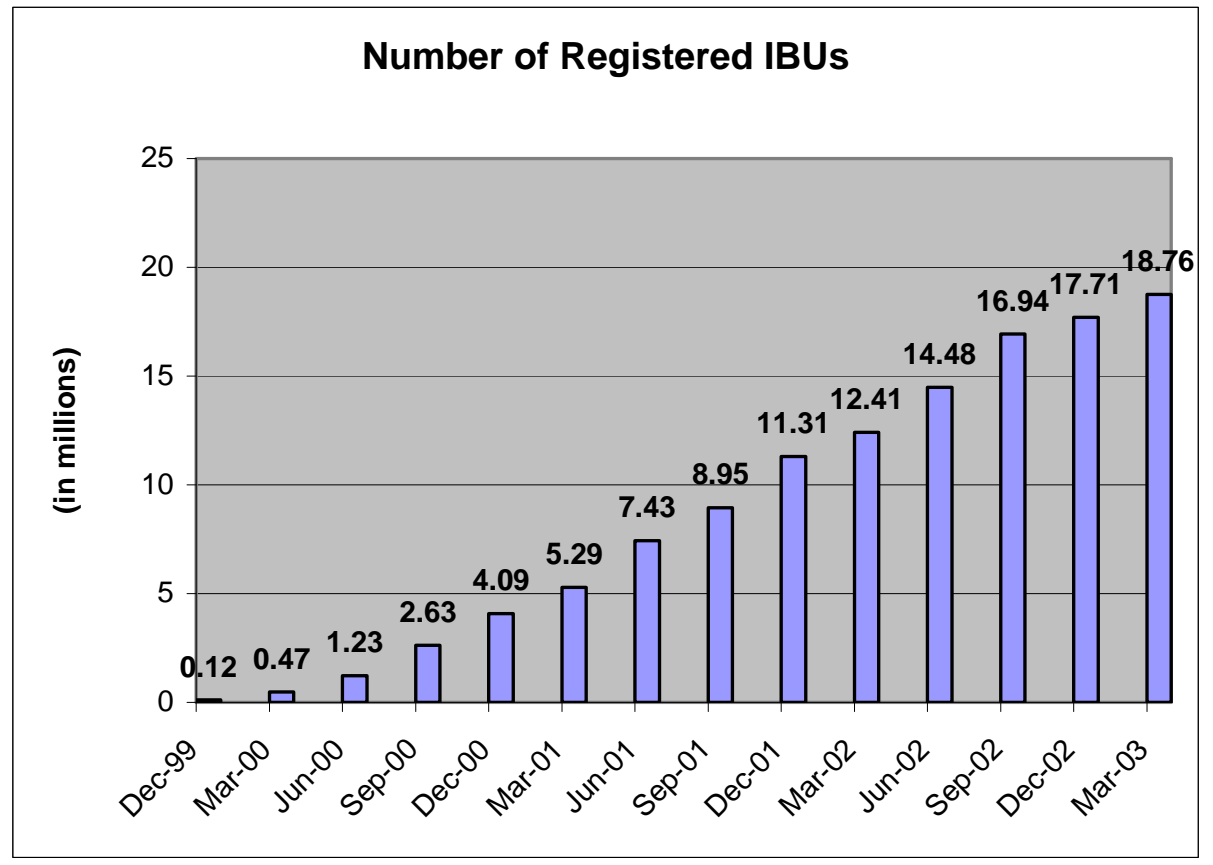

Source: Bank of Korea

Figure 4 Estimated Hazard (Semi-Parametric PH)

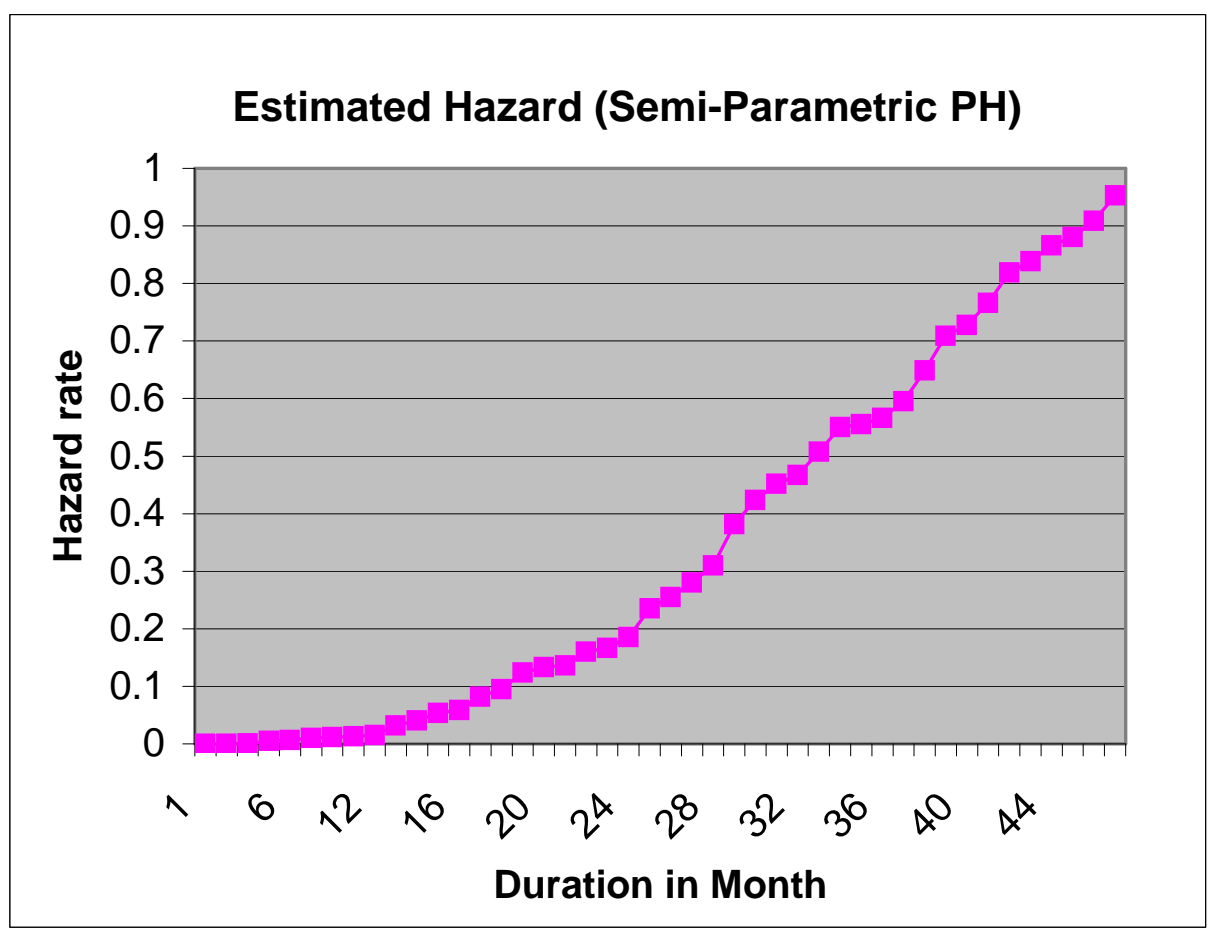


Figure 5 Fully non-parametric estimate (Kaplan-Meier)

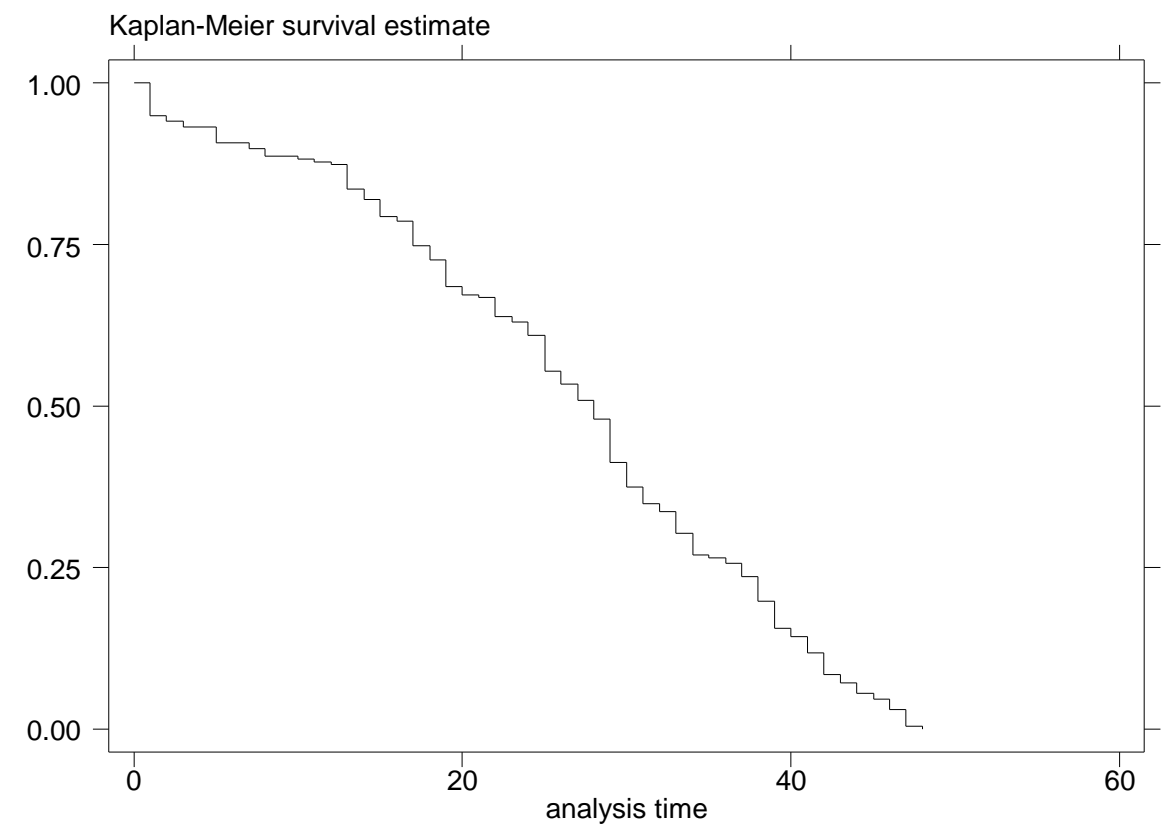

Figure 6 Parametric estimate (Weibull distribution)

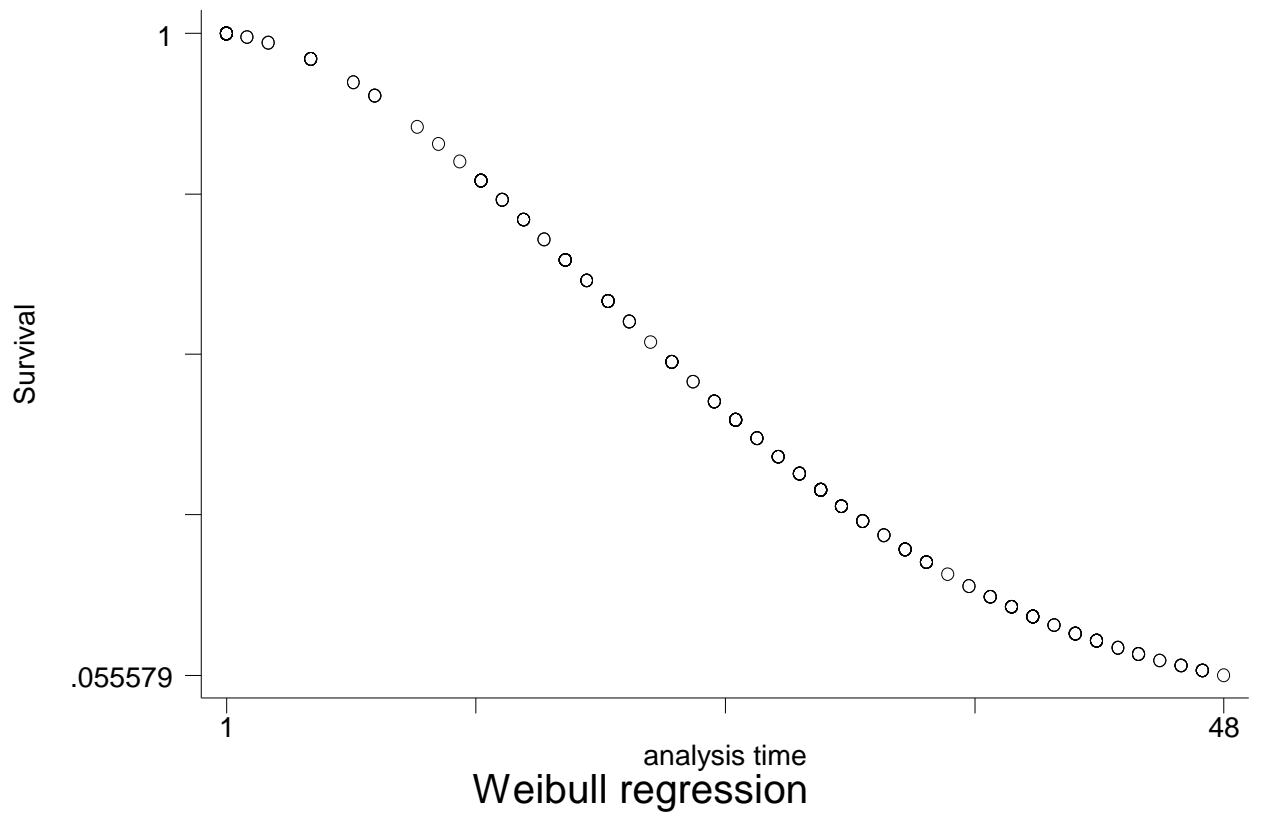


Figure 7 Predicted duration to IB adoption (Weibull)

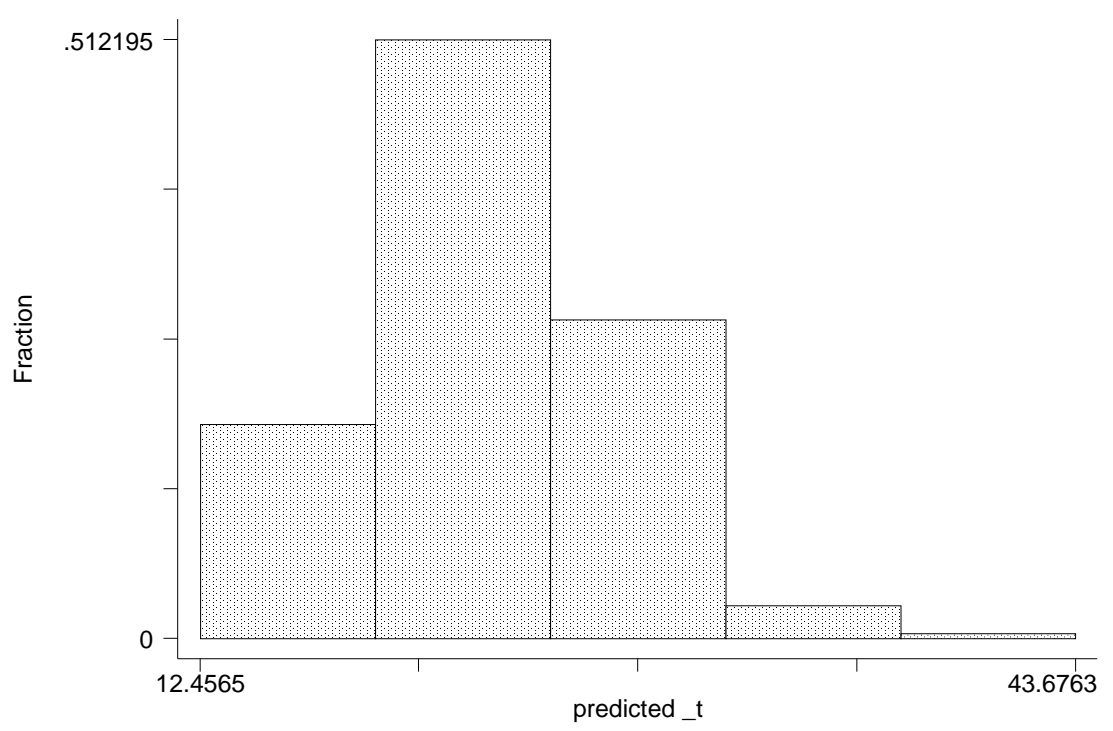

Figure 8 Predicted Hazard (Weibull)

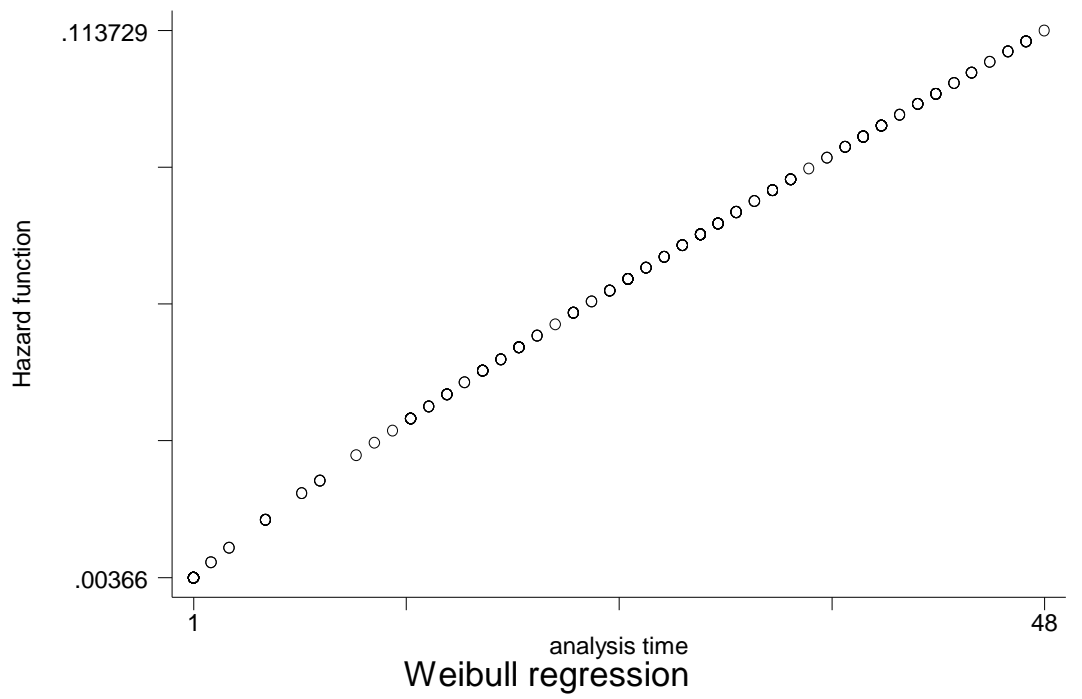


Figure 9 Non-parametric cumulative hazard estimate

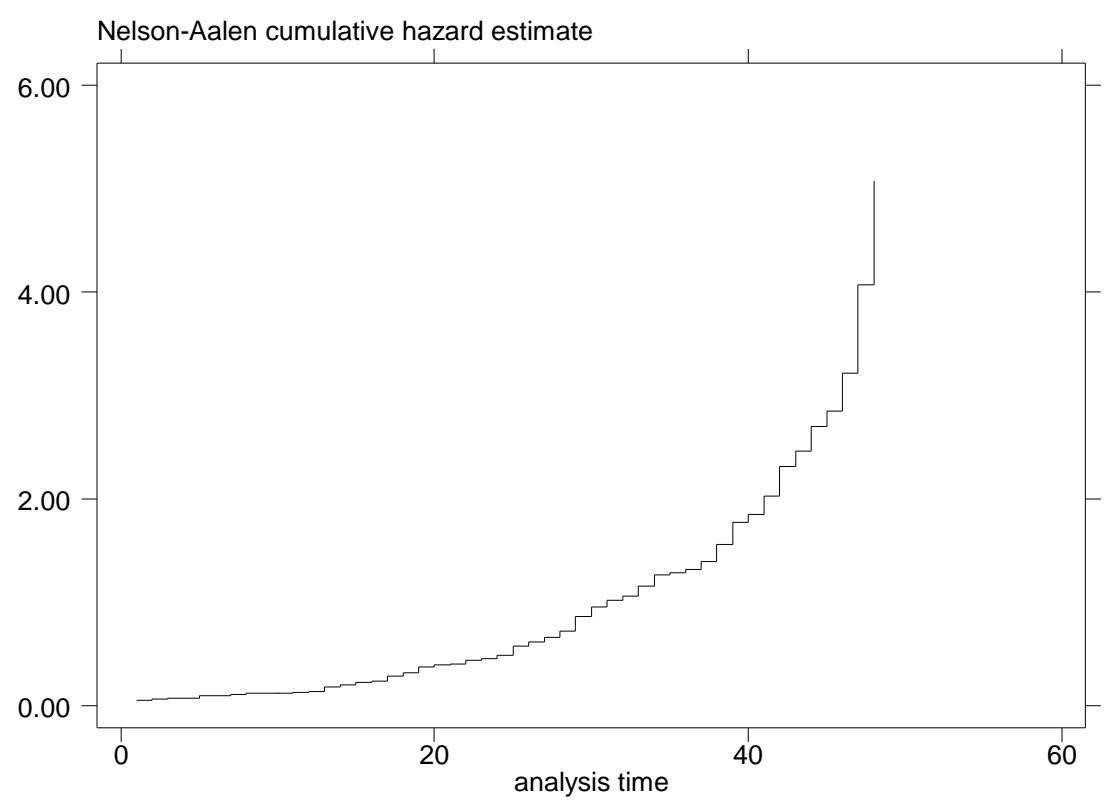

Figure 10 Parametric Weibull cumulative hazard estimate

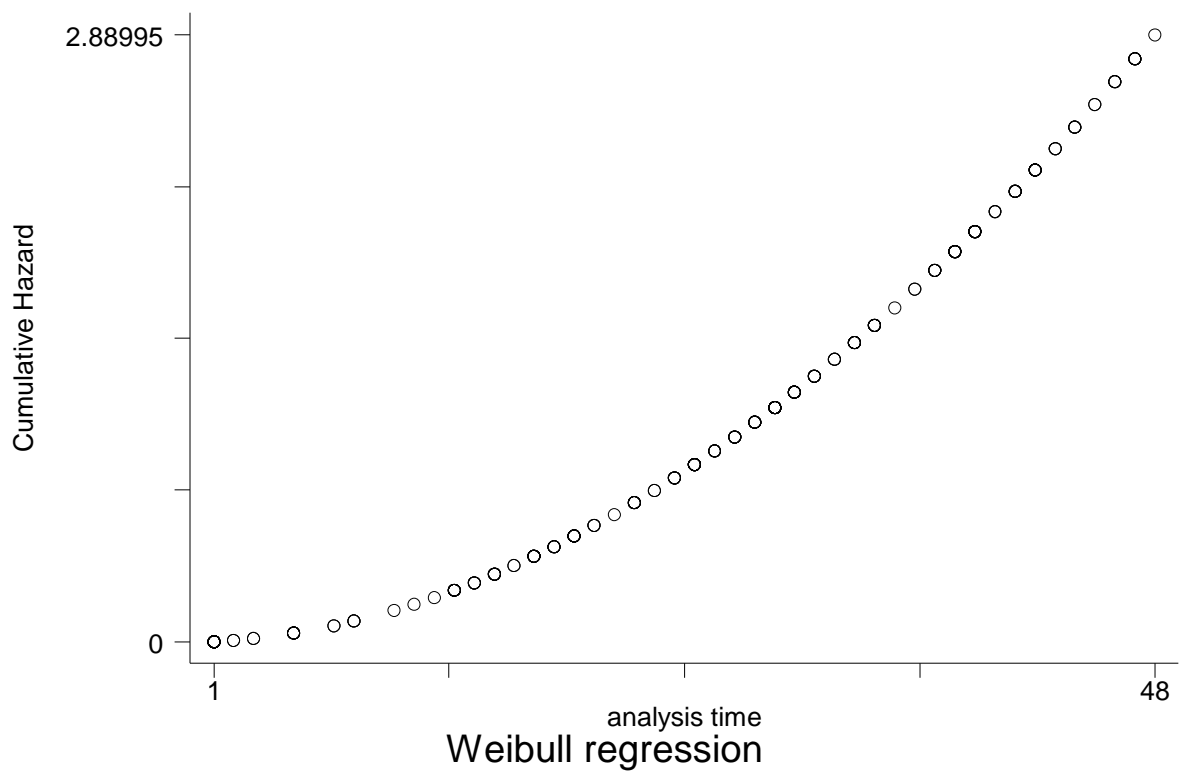




\section{Figure 11 Internet Banking Users in Major Countries}

Intemet Banking $\mathrm{U}$ sers in $\mathrm{M}$ a jig $\mathrm{C}$ ountries

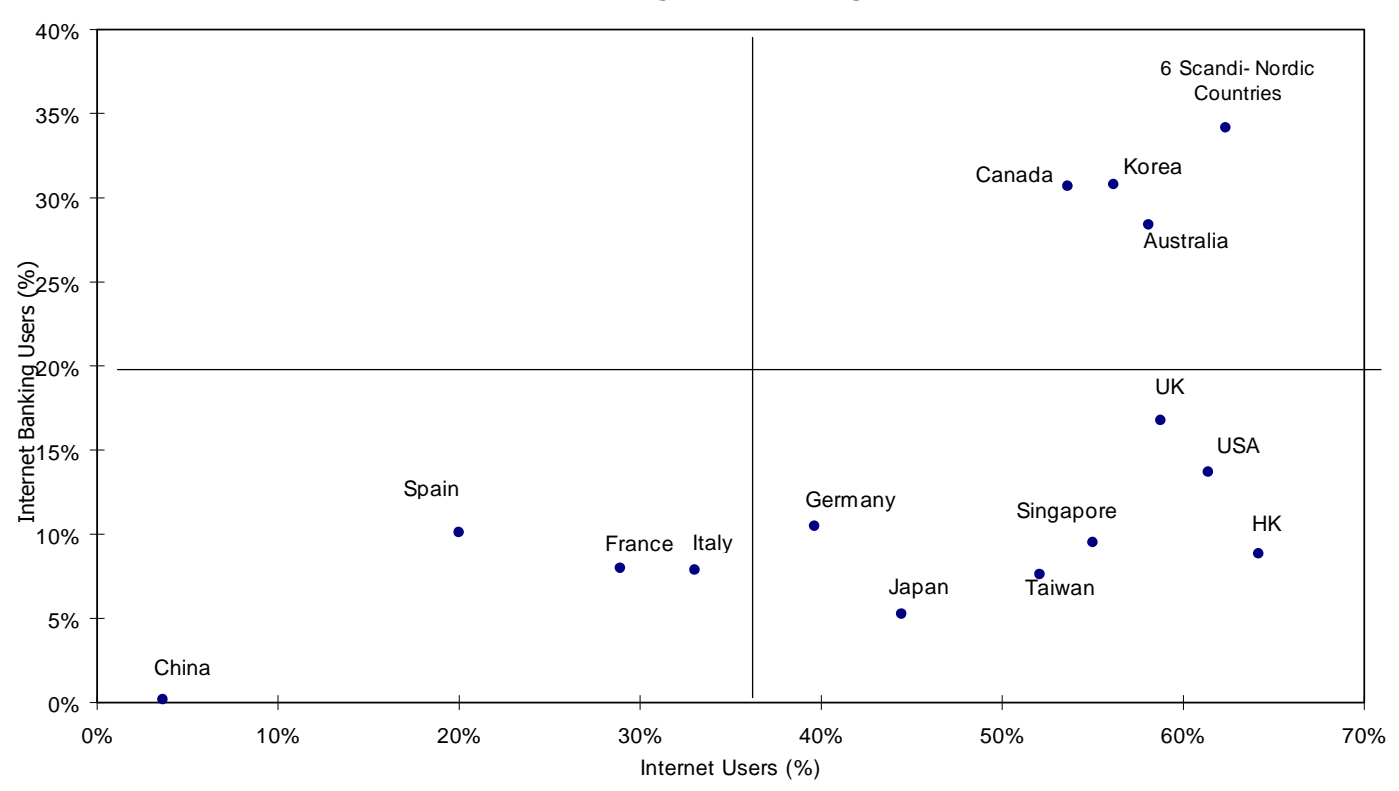

Sournce: Bank of Korea (2002) 
Table 7 Sampling Area for Email Addresses

\begin{tabular}{|c|c|}
\hline $\begin{array}{l}\text { Province } \\
\text { (No. of cities included) }\end{array}$ & City \\
\hline Seoul Metropolitan (1) & Seoul \\
\hline Pusan Metropolitan (2) & Pusan, Haewoondae \\
\hline Kyungki (23) & $\begin{array}{l}\text { Ansan, Anyang, Buchon, Dongduchon, Eujongbu, Euwang, } \\
\text { Inchon, Koonpo, Koyang, Kwachon, Kwangmyung, } \\
\text { Mikeun, Osan, Paju, Pyungtaek, Shihung, Sungnam, } \\
\text { Suwon, Yongin, Yongjin, Ilsan, Icheon, Songtan }\end{array}$ \\
\hline Kangwon (14) & $\begin{array}{l}\text { Chuncheon, Donghae, Heonggye, Heongsung, Hongchon, } \\
\text { Jeongsun, Jomunjin, Kangreung, Samcheok, Sokcho, } \\
\text { Taebaek, Wonju, Youngwol, Wondang }\end{array}$ \\
\hline Chungbuk (2) & Cheongju, Jecheon \\
\hline Chungnam (15) & $\begin{array}{l}\text { Deajeon, Buyeo, Cheonan, Daecheon, Daesan, Gongju, } \\
\text { Hongsung, Jochiwon, Kanggyung, Kwangcheon, Nonsan, } \\
\text { onyang, Seosan, Shintanjin, Sunghwan }\end{array}$ \\
\hline Kyungbuk (11) & $\begin{array}{l}\text { Daegu, Andong, Dalsung, Hayang, Jeomchon, Koomi, } \\
\text { Kyungju, Kyungsan, Pohang, Sangju, Youngcheon }\end{array}$ \\
\hline Kyungnam (18) & $\begin{array}{l}\text { Changnyung, Changwon, Choongmoo, Geochang, } \\
\text { Hamyang, Jangseungpo, Jinhae, Jinju, Kimhae, Kosung, } \\
\text { Masan, Milyang, Namhae, Sacheon, Samcheonpo, Ulju, } \\
\text { Ulsan, Yangsan }\end{array}$ \\
\hline Jeonbuk (9) & $\begin{array}{l}\text { Iri, Jeonju, Koori, Kunsan, Jeongju, Namwon, Kimje, } \\
\text { Buan, Kochang }\end{array}$ \\
\hline Jeonnam (11) & $\begin{array}{l}\text { Kwangju, Haenam, Jangheung, Kangjin, Kwangyang, } \\
\text { Mokpo, Naju, Sooncheon, Wando, Yeochon, Yeosu }\end{array}$ \\
\hline Jeju (1) & Jeju \\
\hline Total 11 provinces & Total 107 cities \\
\hline
\end{tabular}

Table 8 Age Profile Comparison

\begin{tabular}{lcc}
\hline Age Group & Internet User Profile & Survey Sample Profile \\
\hline Ages 6-19 & $38.6 \%$ & $5.3 \%$ \\
20 's & $27.3 \%$ & $32.5 \%$ \\
30 's & $20.7 \%$ & $36.2 \%$ \\
40 's & $10.0 \%$ & $19.5 \%$ \\
50 's & $2.6 \%$ & $4.5 \%$ \\
Over 60 & $0.7 \%$ & $2.0 \%$ \\
Total & $\mathbf{1 0 0 \%}$ & $\mathbf{1 0 0 \%}$ \\
\hline \multicolumn{2}{c}{ Source: KNSO \& MIC 2000 (Internet User Age Profile) }
\end{tabular}




\section{Table 9 Description of Variables}

\begin{tabular}{|c|c|c|}
\hline Variable & Type & Operational Definition \\
\hline \multicolumn{3}{|c|}{ Demographics } \\
\hline Sex & $\mathrm{B} / \mathrm{D}$ & $1=$ Male $; 0=$ Otherwise \\
\hline Age1 & $\mathrm{B} / \mathrm{D}$ & $1=$ if age group $13-24 ; 0=$ otherwise \\
\hline Age2 & $\mathrm{B} / \mathrm{D}$ & $1=$ if age group $25-44 ; 0=$ otherwise \\
\hline Age3 & $\mathrm{B} / \mathrm{D}$ & $1=$ if age group 45 or above; $0=$ otherwise \\
\hline Edu & $\mathrm{B} / \mathrm{D}$ & Education (1=university or above; $0=$ otherwise) \\
\hline Mars & $\mathrm{B} / \mathrm{D}$ & Marital status $(1=$ single, $0=$ otherwise $)$ \\
\hline Marm & $\mathrm{B} / \mathrm{D}$ & Marital status $(1=$ married, $0=$ otherwise $)$ \\
\hline Maro & $\mathrm{B} / \mathrm{D}$ & Marital status ( $1=$ divorced, separated, co-habit, $0=$ otherwise) \\
\hline Inc0 & $\mathrm{B} / \mathrm{D}$ & Personal Income ( $1=$ no income, $0=$ otherwise $)$ \\
\hline Inc1 & $\mathrm{B} / \mathrm{D}$ & Personal Income ( $1=$ up to 3 million won per month, $0=$ otherwise) \\
\hline Inc2 & $\mathrm{B} / \mathrm{D}$ & Personal Income ( $1=$ more than 3 million won per month, $0=$ otherwise) \\
\hline Hse1 & $\mathrm{B} / \mathrm{D}$ & Housing Type ( $1=$ Outright owned; $0=$ otherwise $)$ \\
\hline Area1 & $\mathrm{B} / \mathrm{D}$ & Area of Residence ( $1=$ Seoul metropolitan area; $0=$ otherwise $)$ \\
\hline \multicolumn{3}{|c|}{ Exposure to Internet Banking } \\
\hline $\mathrm{Rc}$ & $\mathrm{B} / \mathrm{D}$ & IB recommended $(1=$ yes; $0=$ otherwise $)$ \\
\hline \multicolumn{3}{|c|}{ Awareness of Information } \\
\hline Irinfo & $\mathrm{B} / \mathrm{D}$ & $\begin{array}{l}\text { Awareness of interest rate information, information seeking behaviour }(1= \\
\text { yes; } 0=\text { otherwise) }\end{array}$ \\
\hline \multicolumn{3}{|c|}{ Banking behaviour } \\
\hline Otcfr & $\mathrm{C}$ & Frequency of visiting bank tellers per month \\
\hline Ibfr & $\mathrm{C}$ & Frequency of visiting banks' website per month \\
\hline \multicolumn{3}{|c|}{ Bank dummies: First Mover \& Largest Bank } \\
\hline Bk1 & $\mathrm{B} / \mathrm{D}$ & First mover dummy ( $1=$ if use the first mover bank; $0=$ otherwise) \\
\hline Bk6 & $\mathrm{B} / \mathrm{D}$ & Market leader dummy ( $1=$ if use the largest bank; $0=$ otherwise $)$ \\
\hline \multicolumn{3}{|c|}{ Internet Banking Adoption } \\
\hline IB & $\mathrm{B} / \mathrm{D}$ & IB used $(1=$ yes; $0=$ otherwise $)$ \\
\hline \multicolumn{3}{|c|}{ Plan to Adopt Internet Banking } \\
\hline Uplan & $\mathrm{B} / \mathrm{D}$ & Plan to use IB ( $1=$ yes; $0=$ otherwise $)$ \\
\hline \multicolumn{3}{|l|}{ Duration } \\
\hline Time & $\mathrm{L} / \mathrm{D}$ & $\begin{array}{l}\text { Time of IB adoption }(1=\text { Jan. } 98 ; 2=\text { Feb. } 98 ; \ldots \text { monthly observation } \\
\text { hereafter) }\end{array}$ \\
\hline
\end{tabular}


Table 10 Questionnaire

\begin{tabular}{|c|c|c|}
\hline Section & $\begin{array}{l}\text { Category } \\
\text { (No. of questions) }\end{array}$ & Question \\
\hline 1. & $\begin{array}{l}\text { Demographics } \\
\text { (10) }\end{array}$ & $\begin{array}{l}\text { Sex, Age, Nationality, Education, Marital status, Type of job, } \\
\text { Personal income, Household income, Type of housing, Area of } \\
\text { residence }\end{array}$ \\
\hline 2. & $\begin{array}{l}\text { Internet Banking } \\
\text { Experience } \\
\text { (3) }\end{array}$ & $\begin{array}{l}\text { 1. Exposure to the internet banking recommendation } \\
\text { 2. Type of recommendation } \\
\text { 3. Have they ever used IB before? }\end{array}$ \\
\hline 3. & $\begin{array}{l}\text { User Group (IBU) } \\
\text { (14) }\end{array}$ & $\begin{array}{l}\text { 1. Timing of adoption (month/year) } \\
\text { 2. Banks dealt with } \\
\text { 3. Main reason for IB adoption } \\
\text { 4. Frequency of internet banking } \\
\text { 5. Average amount dealt via internet banking } \\
\text { 6. Recently used IB services } \\
\text { 7. Initial reason for IB adoption } \\
\text { 8. IB selection criteria } \\
\text { 9. Expected fee savings by IB } \\
\text { 10. Actual fee savings by IB } \\
\text { 11. Cost increase due to IB } \\
\text { 12. Reason for cost increase in adopting IB } \\
\text { 13. Main banking method prior to IB } \\
\text { 14. Location of IB }\end{array}$ \\
\hline 4. & $\begin{array}{l}\text { Non-user Group (NU) } \\
\text { (4) }\end{array}$ & $\begin{array}{l}\text { 1. Reason not to use IB } \\
\text { 2. Do they plan to use? } \\
\text { 3. IB selection criteria if they plan to use IB } \\
\text { 4. Expected fee savings }\end{array}$ \\
\hline 5. & $\begin{array}{l}\text { General banking } \\
\text { (6) }\end{array}$ & $\begin{array}{l}\text { 1. Awareness of interest rate information } \\
\text { 2. Awareness of banks competitiveness } \\
\text { 3. Banking duration (overall commercial banking) } \\
\text { 4. Frequency of OTC visit } \\
\text { 5. Frequency of visit to banks' homepages } \\
\text { 6. IB location believed to be ideal }\end{array}$ \\
\hline
\end{tabular}


Table 11 Descriptive Statistics of Data \& Inequality Tests for Duration

\begin{tabular}{|c|c|c|c|c|c|c|c|}
\hline Variable & Obs & Mean & St.Dev & Min & $\operatorname{Max}$ & $\begin{array}{l}\text { Log-rank } \\
\text { Test }\left(\chi^{2}\right)\end{array}$ & $\begin{array}{l}\text { Wilcoxon } \\
\text { Test }\left(\chi^{2}\right)\end{array}$ \\
\hline $\begin{array}{l}\text { Demographics } \\
\text { Sex } \\
(1=\text { Male })\end{array}$ & 393 & .692 & .462 & 0 & 1 & $\begin{array}{r}17.76 \\
(\mathrm{P}-\text { value}<.001)\end{array}$ & $\begin{array}{r}14.08 \\
(\mathrm{P}-\text { value }<.001)\end{array}$ \\
\hline $\begin{array}{l}\text { Edu } \\
(1=\text { Univ/College } \& \text { above })\end{array}$ & 393 & .847 & .360 & 0 & 1 & $\begin{array}{r}.25 \\
(\mathrm{P}-\text { value }=.618)\end{array}$ & $\begin{array}{r}.01 \\
(\mathrm{P}-\text { value }=.910)\end{array}$ \\
\hline $\begin{array}{l}\text { Age1 } \\
(1=\text { Age } 13-24)\end{array}$ & 393 & .155 & .363 & 0 & 1 & $\begin{array}{r}.21 \\
(\mathrm{P}-\text { value }=.650)\end{array}$ & $\begin{array}{r}1.80 \\
(\mathrm{P}-\text { value }=.179)\end{array}$ \\
\hline $\begin{array}{l}\text { Age2 } \\
(1=\text { Age } 25-44)\end{array}$ & 393 & .748 & .434 & 0 & 1 & $\begin{array}{r}3.52 \\
(\mathrm{P}-\text { value }=.061)\end{array}$ & $\begin{array}{r}.50 \\
(\mathrm{P}-\text { value }=.481)\end{array}$ \\
\hline $\begin{array}{l}\text { Age3 } \\
\text { (1=Age } 45 \& \text { above })\end{array}$ & 393 & .097 & .296 & 0 & 1 & $\begin{array}{r}9.96 \\
(\mathrm{P} \text {-value }=.002)\end{array}$ & $\begin{array}{r}4.61 \\
(\mathrm{P}-\text { value }=.032)\end{array}$ \\
\hline $\begin{array}{l}\text { Mars } \\
(1=\text { Single })\end{array}$ & 393 & .445 & .498 & 0 & 1 & $\begin{array}{r}7.28 \\
(\mathrm{P}-\text { value }=.007)\end{array}$ & $\begin{array}{r}12.78 \\
(\mathrm{P}-\text { value}<.001)\end{array}$ \\
\hline $\begin{array}{l}\text { Marm } \\
(1=\text { Married) }\end{array}$ & 393 & .529 & .500 & 0 & 1 & $\begin{array}{r}4.27 \\
(\mathrm{P}-\text { value }=.039)\end{array}$ & $\begin{array}{r}8.38 \\
(\mathrm{P}-\text { value }=.004)\end{array}$ \\
\hline $\begin{array}{l}\text { Maro } \\
\text { (1=Divorced/separated,etc.) }\end{array}$ & 393 & .025 & .158 & 0 & 1 & $\begin{array}{r}5.28 \\
(\mathrm{P}-\text { value }=.022)\end{array}$ & $\begin{array}{r}3.86 \\
(\mathrm{P}-\text { value }=.050)\end{array}$ \\
\hline $\begin{array}{l}\text { Inc0 } \\
(1=\text { No income })\end{array}$ & 393 & .048 & .215 & 0 & 1 & $\begin{array}{r}1.05 \\
(\mathrm{P}-\mathrm{value}=.306)\end{array}$ & $\begin{array}{r}2.21 \\
(\mathrm{P}-\text { value }=.138)\end{array}$ \\
\hline $\begin{array}{l}\text { Inc1 } \\
(1=<3 \mathrm{mn} \text { KRW p.m. })\end{array}$ & 393 & .662 & .474 & 0 & 1 & $\begin{array}{r}8.78 \\
(\mathrm{P}-\text { value}=.003)\end{array}$ & $\begin{array}{r}12.00 \\
(\mathrm{P}-\text { value}<.001)\end{array}$ \\
\hline $\begin{array}{l}\text { Inc2 } \\
(1=>\text { than } 3 \mathrm{mn} \text { KRW p.m. })\end{array}$ & 393 & .290 & .454 & 0 & 1 & $\begin{array}{r}7.41 \\
(\mathrm{P}-\text { value }=.007)\end{array}$ & $\begin{array}{r}9.57 \\
(\mathrm{P}-\text { value }=.002)\end{array}$ \\
\hline $\begin{array}{l}\text { Hse1 } \\
\text { (1=Outright owned) }\end{array}$ & 393 & .611 & .488 & 0 & 1 & $\begin{array}{r}1.17 \\
(\mathrm{P}-\text { value }=.279)\end{array}$ & $\begin{array}{r}1.19 \\
(\mathrm{P}-\text { value }=.275)\end{array}$ \\
\hline $\begin{array}{l}\text { Area1 } \\
\text { (1=Seoul metropolitan) }\end{array}$ & 393 & .616 & .487 & 0 & 1 & $\begin{array}{r}.91 \\
(\mathrm{P}-\text { value }=.339)\end{array}$ & $\begin{array}{r}1.24 \\
(\mathrm{P}-\text { value }=.265)\end{array}$ \\
\hline $\begin{array}{l}\text { Exposure to Internet Bankin } \\
\text { Rc } \\
(1=\mathrm{IB} \text { recommended })\end{array}$ & 393 & .786 & .410 & 0 & 1 & $\begin{array}{r}5.70 \\
(\mathrm{P}-\text { value }=.017)\end{array}$ & $\begin{array}{r}3.68 \\
(\mathrm{P}-\text { value }=.055)\end{array}$ \\
\hline $\begin{array}{l}\text { Awareness of Information } \\
\text { Irinfo } \\
(1=\mathrm{IR} \text { awareness) }\end{array}$ & 393 & .351 & .478 & 0 & 1 & $\begin{array}{r}6.45 \\
(\mathrm{P}-\text { value }=.011)\end{array}$ & $\begin{array}{r}5.08 \\
(\mathrm{P}-\text { value }=.024)\end{array}$ \\
\hline $\begin{array}{l}\text { Banking Behaviour } \\
\text { Otcfr } \\
\text { (Frequency of OTC visits) }\end{array}$ & 393 & 2.582 & 3.498 & 0 & 30 & $\begin{array}{r}25.24 \\
(\mathrm{P}-\text { value }=.032)\end{array}$ & $\begin{array}{r}24.65 \\
(\mathrm{P}-\text { value }=.038)\end{array}$ \\
\hline $\begin{array}{l}\text { Ibfr } \\
\text { (Freq. of bank Web visits) }\end{array}$ & 393 & 5.548 & 8.108 & 0 & 50 & $\begin{array}{r}73.84 \\
(\mathrm{P}-\text { value}<.001)\end{array}$ & $\begin{array}{r}58.04 \\
(\mathrm{P}-\text { value}<.001)\end{array}$ \\
\hline \multicolumn{8}{|c|}{ Bank dummies: First Mover \& Largest Bank } \\
\hline $\begin{array}{l}\text { Bk1 } \\
\text { (1=First mover dummy) }\end{array}$ & $246^{\circ}$ & .171 & .377 & 0 & 1 & $\begin{array}{r}.91 \\
(\mathrm{P}-\text { value }=.341)\end{array}$ & $\begin{array}{r}.22 \\
(\mathrm{P}-\text { value }=.638)\end{array}$ \\
\hline $\begin{array}{l}\text { Bk6 } \\
\text { (1=Market leader dummy) }\end{array}$ & 246 & .402 & .491 & 0 & 1 & $\begin{array}{r}4.19 \\
(\mathrm{P}-\text { value }=.041)\end{array}$ & $\begin{array}{r}6.10 \\
(\mathrm{P}-\text { value }=.014)\end{array}$ \\
\hline $\begin{array}{l}\text { Internet Banking Adoption } \\
\text { IB }\end{array}$ & 393 & .626 & .484 & 0 & 1 & - & - \\
\hline \multicolumn{8}{|c|}{ Plan to Adopt Internet Banking } \\
\hline Uplan & 147 & .850 & .358 & 0 & 1 & - & - \\
\hline
\end{tabular}


Table 12 Logit Estimation of IB adoption

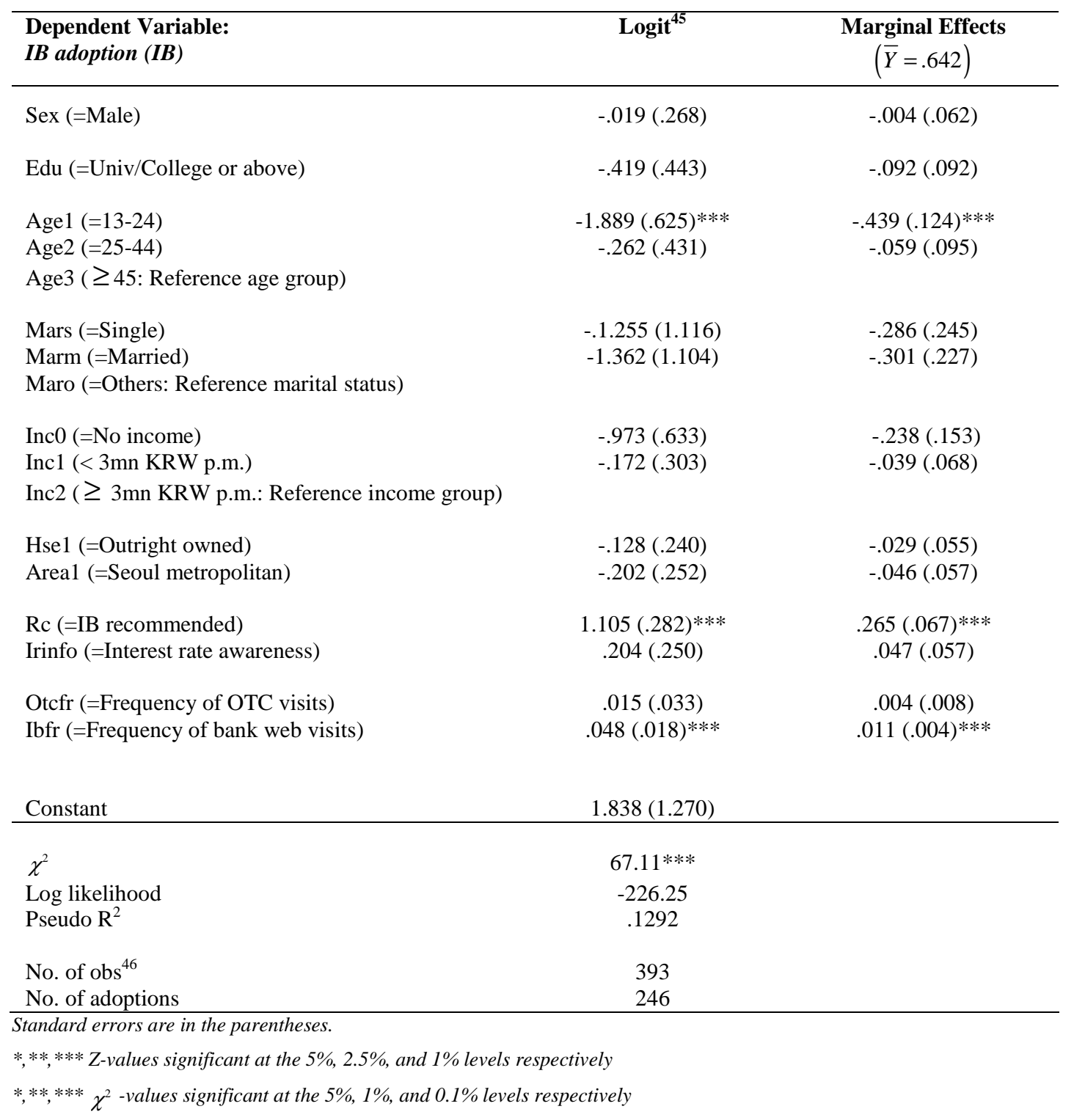

\footnotetext{
${ }^{45}$ The logit specification is a point estimate at the time of survey. Thus, the timing of internet banking adoption is not considered here.

${ }^{46}$ The Weibull baseline hazard model uses 6260 observations of the expanded panel for 48 monthly intervals, whereas the fully non-parametric baseline hazard model excludes the intervals with no event of adoption as well as the last duration interval which has only one adoption event, thus only 5610 observations.
} 
Table 13 Duration Analysis of IB adoption

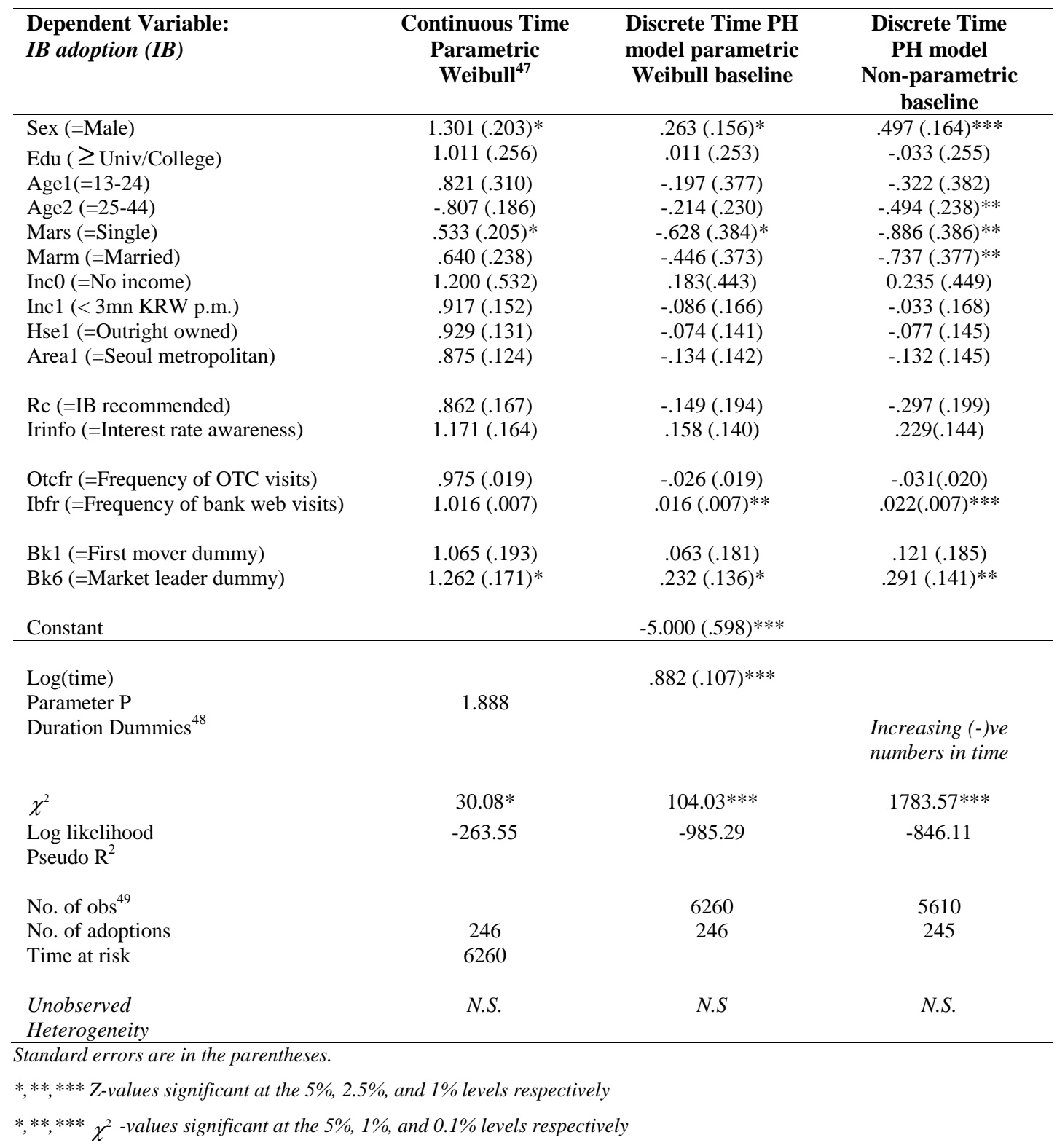

\footnotetext{
${ }^{47}$ The Parametric Weibull estimation shows hazard ratios i.e. if $>1$, it indicates a positive effect on adoption and vice versa.

${ }^{48}$ The coefficients of the duration dummy variables, $\mathrm{d} 1$ to $\mathrm{d} 48$ are non-monotonically increasing from a larger negative number to a smaller negative number, which confirms the baseline hazard of internet banking adoption is increasing over time.

${ }^{49}$ The Weibull baseline hazard model uses 6260 observations of the expanded panel for 48 monthly intervals, whereas the fully non-parametric baseline hazard model excludes the intervals with no event of adoption as well as the last duration interval which has only one adoption event, thus only 5610 observations.
} 
Table 14 Marginal Effects after the Duration Analysis

\begin{tabular}{|c|c|c|c|}
\hline $\mathrm{dy} / \mathrm{dx}$ & $\begin{array}{l}\text { Continuous } \\
\text { Time } \\
\text { Duration } \\
\text { (Weibull) }\end{array}$ & $\begin{array}{c}\text { Discrete Time } \\
\text { Duration } \\
\text { (Weibull } \\
\text { Baseline) }\end{array}$ & $\begin{array}{c}\text { Discrete Time } \\
\text { Duration (Non- } \\
\text { parametric } \\
\text { Baseline) }\end{array}$ \\
\hline $\mathbf{Y}$ & $\begin{array}{l}\text { Predicted Time } \\
\text { of Adoption }\end{array}$ & $\operatorname{Pr}(\text { Ibu })^{50}$ & $\operatorname{Pr}(\mathbf{I b u})$ \\
\hline Mean & 22.522 & .031 & .023 \\
\hline Sex (=Male) & $\begin{array}{l}-3.245 \\
(2.131)\end{array}$ & $\begin{array}{l}.007 * \\
(.004)\end{array}$ & $\begin{array}{l}.010 * * * \\
(.003)\end{array}$ \\
\hline Edu ( $\geq$ Univ/College) & $\begin{array}{c}-.134 \\
(3.037)\end{array}$ & $\begin{array}{l}.000 \\
(.008)\end{array}$ & $\begin{array}{l}-.001 \\
(.006)\end{array}$ \\
\hline Age1(=13-24) & $\begin{array}{c}2.457 \\
(4.958)\end{array}$ & $\begin{array}{l}-.005 \\
(.010)\end{array}$ & $\begin{array}{l}-.006 \\
(.007)\end{array}$ \\
\hline Age2 (=25-44) & $\begin{array}{c}2.476 \\
(2.636)\end{array}$ & $\begin{array}{l}-.007 \\
(.008)\end{array}$ & $\begin{array}{c}-.013 * * \\
(.007)\end{array}$ \\
\hline Mars (=Single) & $\begin{array}{c}7.792 \\
(5.279)\end{array}$ & $\begin{array}{l}-.019 * \\
(.011)\end{array}$ & $\begin{array}{c}-.020 * * \\
(.009)\end{array}$ \\
\hline Marm (=Married) & $\begin{array}{c}5.260 \\
(4.509)\end{array}$ & $\begin{array}{l}-.014 \\
(.012)\end{array}$ & $\begin{array}{l}-.017 * \\
(.009)\end{array}$ \\
\hline Inc0 (=No income) & $\begin{array}{l}-2.082 \\
(4.827)\end{array}$ & $\begin{array}{l}.006 \\
(.016)\end{array}$ & $\begin{array}{l}.006 \\
(.013)\end{array}$ \\
\hline Inc1 (<3mn KRW p.m.) & $\begin{array}{c}1.021 \\
(1.965)\end{array}$ & $\begin{array}{l}-.003 \\
(.005)\end{array}$ & $\begin{array}{l}-.001 \\
(.004)\end{array}$ \\
\hline Hse1 (=Outright owned) & $\begin{array}{c}.880 \\
(1.678)\end{array}$ & $\begin{array}{l}-.002 \\
(.004)\end{array}$ & $\begin{array}{l}-.002 \\
(.003)\end{array}$ \\
\hline Area1 (=Seoul metropolitan) & $\begin{array}{c}1.581 \\
(1.695)\end{array}$ & $\begin{array}{l}. .004 \\
(.004)\end{array}$ & $\begin{array}{l}-.003 \\
(.003)\end{array}$ \\
\hline Rc (=IB recommended) & $\begin{array}{c}1.728 \\
(2.227)\end{array}$ & $\begin{array}{l}-.005 \\
(.007)\end{array}$ & $\begin{array}{l}-.008 \\
(.006)\end{array}$ \\
\hline Irinfo (=Interest rate awareness) & $\begin{array}{l}-1.868 \\
(1.704)\end{array}$ & $\begin{array}{l}.005 \\
(.004)\end{array}$ & $\begin{array}{l}.005 \\
(.004)\end{array}$ \\
\hline Otcfr (=Frequency of OTC visits) & $\begin{array}{l}.305 \\
(.242)\end{array}$ & $\begin{array}{l}-.001 \\
(.001)\end{array}$ & $\begin{array}{l}-.001 \\
(.000)\end{array}$ \\
\hline Ibfr (=Frequency of bank web visits) & $\begin{array}{l}-.186^{*} \\
(.096)\end{array}$ & $\begin{array}{l}.000 \\
(.000)\end{array}$ & $\begin{array}{c}.001 * * * \\
(.000)\end{array}$ \\
\hline Bk1 (=First mover dummy) & $\begin{array}{c}-.741 \\
(2.120)\end{array}$ & $\begin{array}{c}.002 \\
(.006)\end{array}$ & $\begin{array}{c}.003 \\
(.005)\end{array}$ \\
\hline Bk6 (=Market leader dummy) & $\begin{array}{l}-2.744 \\
(1.711)\end{array}$ & $\begin{array}{l}.007 * \\
(.004)\end{array}$ & $\begin{array}{l}.007 * * \\
(.004)\end{array}$ \\
\hline Log (time) & & $\begin{array}{c}.026 * * * \\
(.003)\end{array}$ & \\
\hline
\end{tabular}

Standard errors are in the parentheses.

*,**,*** Z-values significant at the 5\%, 2.5\%, and 1\% levels respectively

\footnotetext{
${ }^{50} \mathrm{Ibu}$ is the dependent variable for the discrete time duration models. This variable is equivalent to IB in the continuous time model.
} 
Table 15 Comparison: Non Users' Future Adoption vs. Overall adoption

\begin{tabular}{|c|c|c|c|}
\hline & $\begin{array}{l}\text { (Model 1) } \\
\text { Logit }\end{array}$ & $\begin{array}{l}\text { (Model 2) } \\
\text { Logit }\end{array}$ & $\begin{array}{c}\text { (Model 3) } \\
\text { Conditional } \\
\text { Logit } \\
(I B=0) \\
\end{array}$ \\
\hline Variable: & $\begin{array}{c}\text { IB adoption } \\
\text { (IB) }\end{array}$ & $\begin{array}{c}\text { Plan to use IB } \\
\text { (Uplan) }\end{array}$ & $\begin{array}{c}\text { Plan to use IB } \\
\text { (Uplan) }\end{array}$ \\
\hline Sex (=Male) & $-.019(.268)$ & $.632(.677)$ & $.594(.757)$ \\
\hline Edu ( $\geq$ Univ/College $)$ & $-.419(.443)$ & $.159(1.224)$ & $1.364(2.133)$ \\
\hline Age1(=13-24) & $-1.889(.625)^{* * *}$ & $1.799(1.778)$ & $1.339(1.285)$ \\
\hline Age2 $(=25-44)$ & $-.262(.431)$ & $-.221(1.239)$ & $-.357(2.498)$ \\
\hline Mars (=Single $)^{51}$ & $-.1 .255(1.116)$ & - & - \\
\hline Marm (=Married) & $-1.362(1.104)$ & $-.759(.683)$ & $-.720(.682)$ \\
\hline Inc0 (=No income) & $-.973(.633)$ & $.582(1.183)$ & $.589(2.049)$ \\
\hline Inc1 (<3mn KRW p.m.) & $-.172(.303)$ & $.537(.777)$ & $.492(1.235)$ \\
\hline Hse1 (=Outright owned) & $-.128(.240)$ & $1.278(.571)^{* *}$ & $1.146(.568)^{* *}$ \\
\hline Area1 (=Seoul metropolitan) & $-.202(.252)$ & $-.420(.655)$ & $-.375(1.084)$ \\
\hline Rc (=IB recommended) & $1.105(.282)^{* * *}$ & $.986(.579)^{*}$ & $.930(.592)$ \\
\hline Irinfo (=Interest rate awareness) & $.204(.250)$ & $-.378(.659)$ & $-.241(1.018)$ \\
\hline Otcfr (=Frequency of OTC visits) & $.015(.033)$ & $.175(.142)$ & $.137(.125)$ \\
\hline $\begin{array}{l}\text { Ibfr (=Frequency of bank web } \\
\text { visits) }\end{array}$ & $.048(.018)^{* * *}$ & $.227(.133)^{*}$ & $.135(.083)$ \\
\hline Constant & $1.838(1.270)$ & $-1.666(1.987)$ & \\
\hline$\chi^{2}$ & $67.11 * * *$ & $30.26 * *$ & $30.10^{* *}$ \\
\hline Log likelihood & -226.25 & -46.92 & -44.62 \\
\hline Pseudo $\mathrm{R}^{2}$ & .1292 & .2438 & .2522 \\
\hline No. of obs. & 393 & 147 & 147 \\
\hline No. of events & 246 & 125 & 125 \\
\hline
\end{tabular}

$*, * *, * * * Z$-values significant at the $5 \%, 2.5 \%$, and $1 \%$ levels respectively

$*, * *, * * * \chi^{2}$-values significant at the $5 \%, 1 \%$, and $0.1 \%$ levels respectively

\footnotetext{
${ }^{51}$ The variable, Mars was omitted from Model 2 and Model 3 due to hidden collinearity, which arise when the independent variables are all dummy variables and/or continuous variables with multiple values.
} 
Table 16 Plan to Use IB (Uplan): Marginal Effects at Mean

\begin{tabular}{|c|c|c|}
\hline $\begin{array}{l}\text { Mean } \\
.936\end{array}$ & $\operatorname{Pr}($ Uplan $)$ & $d y / d x$ \\
\hline Sex (=Male) & $\begin{array}{l}.632 \\
(.677)\end{array}$ & $\begin{array}{l}.041 \\
(.049)\end{array}$ \\
\hline Edu ( $\geq$ Univ/College) & $\begin{array}{c}.159 \\
(1.224)\end{array}$ & $\begin{array}{l}.143 \\
(.155)\end{array}$ \\
\hline $\operatorname{Age1}(=13-24)$ & $\begin{array}{l}1.799 \\
(1.778)\end{array}$ & $\begin{array}{l}.085 \\
(.074)\end{array}$ \\
\hline Age2 (=25-44) & $\begin{array}{c}-.221 \\
(1.239)\end{array}$ & $\begin{array}{l}-.013 \\
(.071)\end{array}$ \\
\hline Mars (=Single) & - & - \\
\hline Marm (=Married) & $\begin{array}{l}-.759 \\
(.683)\end{array}$ & $\begin{array}{l}-.047 \\
(.046)\end{array}$ \\
\hline Inc0 (=No income) & $\begin{array}{c}.582 \\
(1.183)\end{array}$ & $\begin{array}{l}.028 \\
(.048)\end{array}$ \\
\hline Inc1 (<3mn KRW p.m.) & $\begin{array}{l}.537 \\
(.777)\end{array}$ & $\begin{array}{l}.036 \\
(.057)\end{array}$ \\
\hline Hse1 (=Outright owned) & $\begin{array}{l}1.278 \\
(.571)^{* *}\end{array}$ & $\begin{array}{l}.090^{*} \\
(.050)\end{array}$ \\
\hline Area1 (=Seoul metropolitan) & $\begin{array}{l}-.420 \\
(.655)\end{array}$ & $\begin{array}{l}-.026 \\
(.038)\end{array}$ \\
\hline Rc (=IB recommended) & $\begin{array}{c}.986 \\
(.579)^{*}\end{array}$ & $\begin{array}{l}.070 \\
(.051)\end{array}$ \\
\hline Irinfo (=Interest rate awareness) & $\begin{array}{l}-.378 \\
(.659)\end{array}$ & $\begin{array}{l}-.024 \\
(.046)\end{array}$ \\
\hline Otcfr (=Frequency of OTC visits) & $\begin{array}{l}.175 \\
(.142)\end{array}$ & $\begin{array}{l}.010 \\
(.009)\end{array}$ \\
\hline Ibfr (=Frequency of bank web visits) & $\begin{array}{c}.227 \\
(.133)^{*}\end{array}$ & $\begin{array}{l}.014 * * \\
(.006)\end{array}$ \\
\hline
\end{tabular}

Standard errors are in the parentheses.

$*, * *, * * *$-values significant at the $5 \%, 2.5 \%$, and $1 \%$ levels respectivel 


\section{References}

Akhavein, J., Frame, W.S., and L.J. White (2001), "The Diffusion of Financial Innovations: An Examination of the Adoption of Small Business Credit Scoring by Large Banking Organizations," mimeo, Stern School of Business, NYU

Arulampalam, W., Naylor, R. A. and J. P. Smith (2001), "A Hazard Model of the Probability of Medical School Dropout in the United Kingdom," mimeo, University of Warwick

Becker, M.H. (1970), "Sociometric Location and Innovativeness: Reformulation and Extension of the Diffusion Model," American Sociological Review, Vol.35, No.2, pp.267-282

Birkhchandani S., Hirshleifer D., and I. Welch (1998), "Learning from the Behaviour of Others: Conformity, Fads, and informational Cascades," Journal of Economic Perspectives, Vol.12, No.3, pp.151-170

Casson, M. (1997), Culture, Social Norms and Economics: Economic Performance, Edward Elgar Publishing Ltd.

Cave, M. and R. Mason (2001), "The Economics and Regulation of the Internet”, mimeo, University of Brunel

Cowling, K. and R. Naylor (1992), “Norms, Sovereignty and Regulation”, Metroeconomica, Vol.43, No.1-2, pp.177-204

Cronin, M.J. (1997), Banking and Finance on the Internet, VNR

Davies, S. (1979), The Diffusion of Process Innovations, Cambridge University Press

Dewatripont, M. and J. Tirole (1994), The Prudential Regulation of Banks, MIT Press

Diniz, E. (1998), "Web Banking in USA", Journal of Internet Banking and Commerce, Vol.3, No.2, http://www.arraydev.com/commerce/JIBC/9806-06.htm

Farrell, J. and G. Saloner (1986), "Installed Base and Compatibility: Innovation, Product Preannouncements, and Predation", The American Economic Review, Vol.76. Issue 5, pp.940-955

Freixas, X. and J.C. Rochet (1997), Microeconomics of Banking, MIT Press

Fudenberg, D. and J. Tirole (1985), "Preemption and Rent Equalization in the Adoption of New Technology", Review of Economic Studies, Vol. 52, pp.383-401

Geroski, P. (2000), “’'Models of Technology Diffusion”, Research Policy, Vol.29, pp.603-625

Gilbert, R. and D. Newbery (1982), "Preemptive Patenting and the Persistence of Monopoly", American Economic Review, Vol. 72, pp.514-526

Greene, W.H. (2000), Econometric Analysis $4^{\text {th }}$ edition, Prentice Hall 
Greif, A. (1994), "Cultural Beliefs and the Organization of Society: A Historical and Theoretical Reflection on Collectivist and Individualist Societies", Journal of Political Economy, Vol.102, Issue 5, pp.912-950

Gourlay, A. and E. Pentecost (2002), "The Determinants of Technology Diffusion: Evidence from the UK Financial Sector", The Manchester School. Vol.70, No.2, pp.185-203

Hannan, T.H. and J.M. McDowell (1984), "The Determinants of technology adoption: the case of the banking firm", Rand Journal of Economics, Vol.15, No.3, pp.328-335

Hannan, T.H. and J.M. McDowell (1986), "Rival Precedence and the Dynamics of Technology Adoption: an Empirical Analysis", Economica Vol.54, pp.155-171

Hannan, T.H. and J.M. McDowell (1990), "The impact of technology adoption on market structure", The Review of Economics and Statistics, Vol.72, Issue 1, pp.164-168.

Hannan, T.H. (1991), "Foundations of the Structure Conduct Performance Paradigm in Banking”, Journal of Money, Credit and Banking, Vol. 23, No. 1, pp. 68-84

Hoppe, H.C. (2002), “The Timing of New Technology Adoption: Theoretical Models and Empirical evidence", The Manchester School Vol.70, No.1, pp.56-76

Janelli, R.L. and D. Yim (1997), "The Mutual Constitution of Confucianism and Capitalism in South Korea", in Culture and Economy: The Shaping of Capitalism in Eastern Asia (edited by T. Brook and HY V. Luong), The University of Michigan Press

Jenkins, S. P. (2002), "Survival Analysis (stb.doc)", http://www.iser.essex.ac.uk/teaching/stephenj/ec968/zips/pgmhaz.zip

Joyce, J.P (2001), “Time Present and Time Past: A Duration Analysis of IMF Program Spells", Federal Reserve Bank of Boston Working Paper No.01-2

Kalbfleisch, J.D., and R.L. Prentice (1980), The Statistical Analysis of Failure Time data, John Wiley and Sons, Inc.

Kaplan, E.L. and P. Meier (1958), "Nonparametric Estimation from Incomplete Observations", Journal of the American Statistical Association, Vol.53, Issue 282, pp.457-481

Karchenas, M. and P. L. Stoneman (1993), "Rank, Stock, Order, and Epidemic Effects in the Diffusion of New process Technologies: An Empirical Model", The Rand Journal of Economics, Vol.24. Issue 4, pp.503-528

Karshenas, M. and P. Stoneman (1995), “Technological Diffusion”, in Stoneman (ed.), Handbook of the Economics of Innovation and Technological Change, Blackwell Publishers

Katz, M.L. and C. Shapiro (1985), "Network Externalities, Competition and compatibility", The American Economic Review, Vol. 75, Issue 3, pp.424-440

Katz, M.L. and C. Shapiro (1986), "Technology Adoption in the Presence of Network Externalities", The Journal of Political Economy, Vol. 94, Issue 4, pp.822-841 
Kiefer, N. M. (1988), "Economics Duration Data and Hazard Functions", Journal of Economics Literature, Vol. 24, pp.646-679

Lancaster, T. (1990), The Econometric Analysis of Transition Data, Cambridge University Press

Macdonald, D.S. (1990), The Koreans: Contemporary Politics and Society, $2^{\text {nd }}$ ed., Westview Press

Mansfield, E. (1968), The Economics of Technical Change, New York, Norton.

Mason, R. and H. Weeds (2001), "Networks, Options and Pre-emption”, mimeo, University of Southampton

McFadden, D.L. and K.E. Train (1996), "Consumers' Evaluation of New Products: Learning from Self and Others", The Journal of Political Economy, Vol.104, No.4, pp. 683-703

Meyer, B.D. (1990), "Unemployment Insurance and Unemployment Spells", Econometrica, vol.58, Issue 4, pp.757-782

Narendranathan, W. and M.B. Stewart (1993), "Modelling the Probability of Leaving Unemployment: Competing Risks Models with Flexible Base-Line Hazards", Applied Statistics, Vol.42, Issue 1, pp.63-83

Naylor, R. (1989), "Strikes, Free Riders and Social Customs”, Quarterly Journal of Economics, Vo.104, Issue 4, pp.771-785

Novo-Peteiro, J.A. (2000), "New Technology, Information Reusability and Diversification: A Simple Model of a Banking Firm", Information Economics and Policy 12, pp.69-88

Reinganum, J.F. (1981a), "On the Diffusion of New Technology: a Game Theoretic Approach", Review of Economic Studies, Vol. 48, pp.395-405

Reinganum, J.F. (1981b), "Market Structure and the Diffusion of New Technology", Bell Journal of Economics, vol.12, pp.618-624

Rodriguez, G. (2001), "Chapter 7. Survival Models", http://data.princeton.edu/wws509/notes/c7.pdf.

Rose N.L. and P.L. Joskow (1990), "The diffusion of new technologies: evidence from the electric utility industry", Rand Journal of Economics, Vol. 21, No.3, pp.354-373

Rosenberg, N. (1976), "On technological expectations", The Economic Journal, Vol.6, Issue 3, pp.523-535

Rogers, E.M. (1995), Diffusion of Innovations, $4^{\text {th }}$ ed., Free Press

Saloner, G. and A. Shepard (1995), "Adoption of Technologies with Network Effects: An Empirical Examination of the Adoption of Automated Teller Machines", Rand Journal of Economics, Vol. 26, Issue 3, pp.479-501

Schumpeter, J.A. (1934), The Theory of Economic Development, Cambridge (Mass): Harvard University Press 
Schumpeter, J.A. (1943), Capitalism, Socialism and Democracy, London: Allen \& Unwin

Shapiro, C. and H.R. Varian (1999), Information Rules - A Strategic Guide to the Network Economy, HBS press

Solow, R. (1957), "Technical Change and the Aggregate Production Function", Review of Economics and Statistics, Vol. 34, pp.312-320

Spiegel, M.R. (1992), Theory and Problems of Probability and Statistics, New York MacGraw Hill

Stoneman, P. and G. Battisti (2000), "The Role of Regulation, Fiscal Incentives and Changes in Tastes in the Diffusion of Unleaded Petrol", Oxford Economic Papers, Vol.52, pp.326-356

Stoneman, P. and P. Dierderen (1994), "Technology Diffusion and Public Policy", The Economic Journal, Vol.104, Issue 425, pp.918-930

Sutton J. (1998), Technology and Market Structure, MIT Press

Tarde, G. (1903), The Laws of Imitation (Les Lois de l'Imitation, 1890), translated by E.C. Parsons, New York, Henry Holt and Company

Waterson, M. (2001), "The Role of Consumers in Competition and Competition Policy", mimeo, University of Warwick

Weiss, A.M. (1994), "The Effects of Expectations on Technology Adoption: Some Empirical Evidence", Journal of Industrial Economics, Vol.42, No.4, pp. 341-360. 